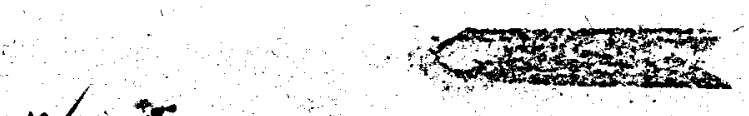

June 1980

REMOVAL OF SILICA FROM

RAFT RIVER GEOTHERMAL WATER

3

t.

\title{
MASTER
}

D. F. Suciu

R. L. Miller

\section{U.S. Department of Energy}

Idaho Operations Office • Idaho National Engineering Laboratory

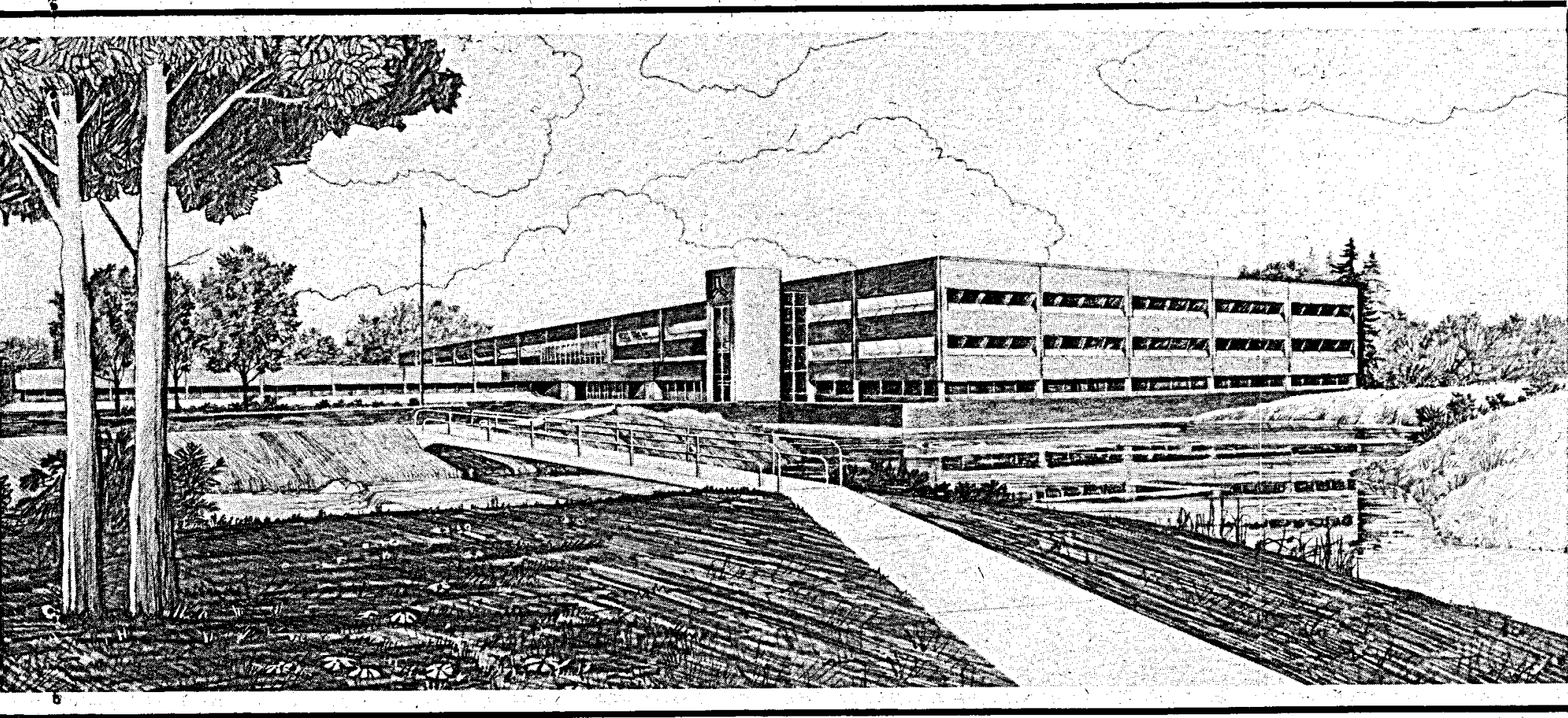

This is an informal report intended for use as a preliminary or working document

Prepared for the

U.S. Department of Energy

Idaho Operations office

Under DOE Contract NO. DE-AOO7-76IDO1570

DISTRIBUTION OF TMIS DOSUREETT IS UNUMHTED

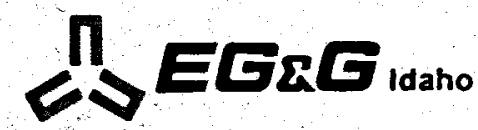




\section{DISCLAIMER}

This report was prepared as an account of work sponsored by an agency of the United States Government. Neither the United States Government nor any agency Thereof, nor any of their employees, makes any warranty, express or implied, or assumes any legal liability or responsibility for the accuracy, completeness, or usefulness of any information, apparatus, product, or process disclosed, or represents that its use would not infringe privately owned rights. Reference herein to any specific commercial product, process, or service by trade name, trademark, manufacturer, or otherwise does not necessarily constitute or imply its endorsement, recommendation, or favoring by the United States Government or any agency thereof. The views and opinions of authors expressed herein do not necessarily state or reflect those of the United States Government or any agency thereof. 


\section{DISCLAIMER}

Portions of this document may be illegible in electronic image products. Images are produced from the best available original document. 


\section{DISCLAIMER}

This book was prepared as an account of work sponsored by an agency of the United States Government. Neither the United States Government nor any agency thereof, nor any of their employees, makes any warranty, express or implied, or assumes any legal liability or responsibility for the accuracy. completeness, or usefulness of any information, apparatus, product or process disclosed, or represents that its use would not infringe privately owned rights. References herein to any specific commercial product, process, or service by trade name, trademark, manufacturer, or otherwise, does not necessarily constitute or imply its endorsement, recommendation, or favoring by the United States Government or any agency thereof. The views and opinions of authors expressed herein do not necessarily state or reflect those of the United States Government or any agency thereof. 
REMOVAL OF SILICA FROM

RAFT RIVER GEOTHERMAL WATER

D. F. Suciu

R. L. Miller

Published June 1980

EG\&G Idaho, Inc. Idaho Falls, Idaho 83415

\author{
Prepared for the \\ U. S. Department of Energy \\ Idaho Operations of fice \\ Under DOE Contract No. DE-ACO7-76ID01570
}




\section{ACKNOWLEDGEMENTS}

Special thanks are extended to Richard N. Wallace, District Representative for Betz Laboratories, Inc.; A. B. Mindler; Research and Development Division, Permutit Corporation; D. A. Conley, Materials Science Branch, for his contributions to the Raft River Geothermal Test Project; and INEL Library personnel. 


\section{ABSTRACT}

Lack of sufficient quantities of clean surface or near-surface water at Raft River for cooling purposes dictates that cooled geothermal fluid, effluent from the Raft River 5 MW(e) Pilot Power Plant, must also be used as condenser coolant. Prior testing revealed that a water-treatment system would be required to reduce silica and calcium concentrations of the cooling fluid. The water-treatment system specified by the Department of Energy's Architect-Engineer was to use dolomitic lime for both pH adjustment and source of magnesium. The dolomitic lime treatment was investigated and found to be inadequate. Subsequent testing was done to find chemical systems that would adequately reduce silica concentrations. Three magnesium and two iron compounds were found which reduced silica to acceptable concentration levels. They are magnesium bicarbonate, magnesium chloride, magnesium sulfate, iron sulfate, and iron chloride. Magnesium oxide, using a two-stage countercurrent process, will also reduce silica to adequate levels. 
ACKNOWLEDGEMENTS $\ldots \ldots \ldots \ldots \ldots \ldots \ldots \ldots \ldots \ldots \ldots \ldots \ldots \ldots \ldots \ldots \ldots \ldots \ldots$

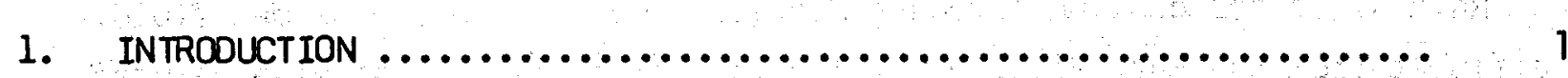

2. LiteratURE SEARCH. ................................... 4

2.1 Silica Reduction Mechanisms................................ 4

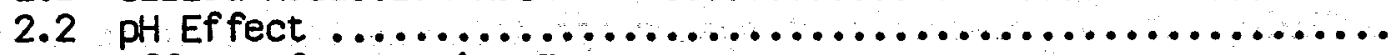

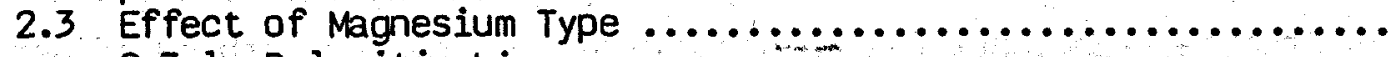

2.3.1 Dolomitic Lime ...............................

2.3.2 Nondissolved Magnesium Compounds ..................

2.3.3 Dissolved Magnesium Compounds (Salts) ................

3. DESIGN SPECIFICATIONS $\ldots \ldots \ldots \ldots \ldots \ldots \ldots \ldots \ldots \ldots \ldots \ldots \ldots \ldots \ldots \ldots \ldots \ldots \ldots \ldots \ldots \ldots \ldots$

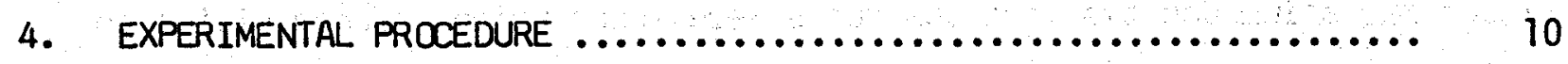

4.1 Jar Tests $\ldots \ldots \ldots \ldots \ldots \ldots \ldots \ldots \ldots \ldots \ldots \ldots \ldots \ldots \ldots \ldots, 10$

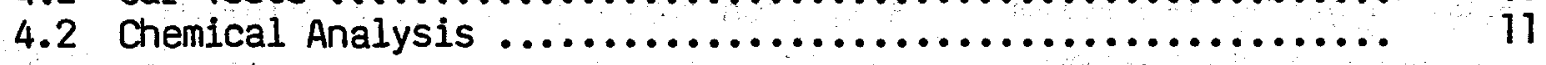

5. EVALUATION OF SYSTEM SPECIFIED BY THE ARCHITECT-ENGINEER........ 13

5.1 Dolomitic Lime ........................................ 13

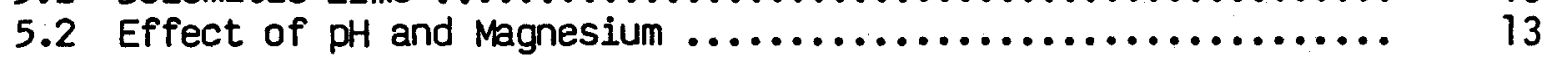

5.3 Temperature Ef fect $\ldots \ldots \ldots \ldots \ldots \ldots \ldots \ldots \ldots \ldots \ldots \ldots \ldots \ldots \ldots \ldots \ldots \ldots \ldots \ldots \ldots \ldots \ldots, 14$

6. EVALUATION OF MAGNESTUM OXIDE SYSTEMS $\ldots \ldots \ldots \ldots \ldots \ldots \ldots \ldots \ldots \ldots$

6.1 Effect of Grade of Magnesium Oxide .................... 16

6.2 Temperature Effect Evaluation Using Remosil.................. 16

6.3 Dolomitic Lime Plus Remosil ............................. 17

6.4 High Doncentrations of Magnesium Oxide $\ldots \ldots \ldots \ldots \ldots \ldots \ldots . .18$

6.5 Preliminary Conclusions of Magnesium Oxide Systems .......... 18

7. TWO-STAGE COUNTERCARRENT PROCESS UNIT .................... 19

8. SQLUBLE MAGNESIUM COMPOUND SYSTEMS $\ldots \ldots \ldots \ldots \ldots \ldots \ldots \ldots \ldots \ldots . . \ldots \ldots$

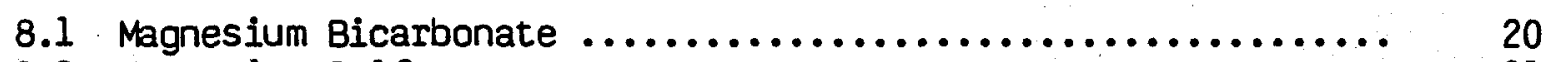

8.2 Magnesium Sulfate $\ldots \ldots \ldots \ldots \ldots \ldots \ldots \ldots \ldots \ldots \ldots \ldots \ldots \ldots \ldots \ldots \ldots \ldots \ldots \ldots, 21$

8.3 Magnesium Chloride $\ldots \ldots \ldots \ldots \ldots \ldots \ldots \ldots \ldots \ldots \ldots \ldots \ldots \ldots \ldots \ldots \ldots \ldots \ldots \ldots \ldots, 24$

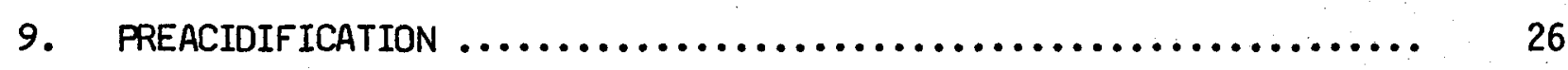

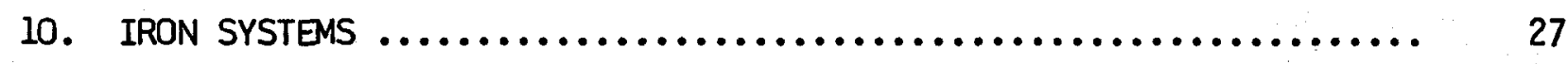

11. DISCUSSION OF RESULTS $\ldots \ldots \ldots \ldots \ldots \ldots \ldots \ldots \ldots \ldots \ldots \ldots \ldots \ldots . \ldots \ldots$ 


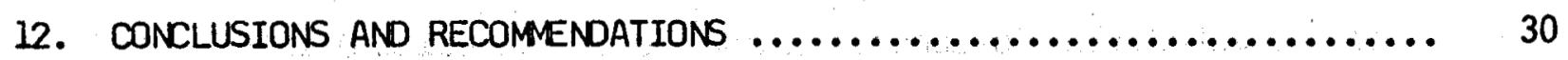

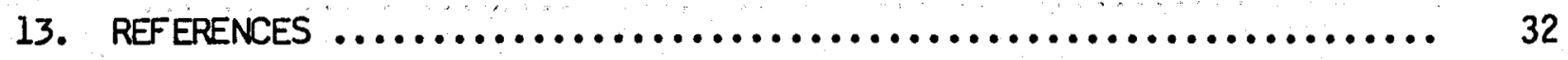

APPENDIX A - ANALYSIS OF WATER TREATED WITH VARIOUS SYSTEMS ......... 37

FIGURES

1. Volume of make-up required at various cycles of concentration ..... 3

2. Log percent transmittance versus concentration of silica $\ldots \ldots \ldots \ldots, 12$

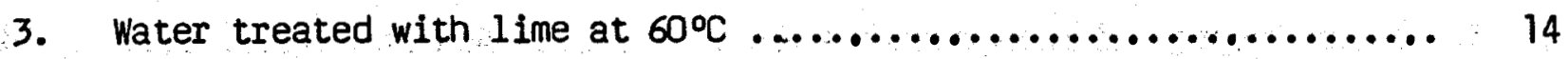

4. Concentration of residual silica versus concentration of magnesium added as (a) Epsom salt, (b) Epsom salt plus soda ash, and (c) Epsom salt plus sodium bicarbonate ............ 22

5. Concentration of residual silica versus concentration of (a) magnesium oxide plus sulfuric acid and (b) magnesium oxide plus soda ash and sulfuric acid.

6. Concentration of residual silica versus concentration of magnesium oxide plus hydrochloric acid at fixed $\mathrm{pH}$

\section{TABLES}

1. Make-up and Blowdown Rates for Different Cycles

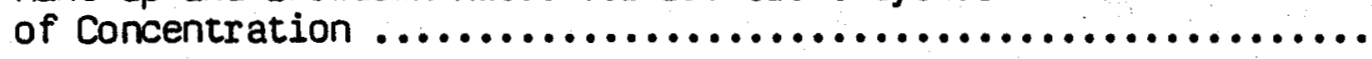

2. Analysis of Filtered Samples of Magnesium Hydroxide

Slurries After Bubbling Carbon Dioxide to Constant $\mathrm{pH} . . . \ldots \ldots .20$

A-1. Water Treated with Dolomitic Lime at $60^{\circ} \mathrm{C} \ldots \ldots \ldots \ldots \ldots \ldots . . . . . .39$

A-2. Water Treated with Dolomitic Lime at Four Temperatures ........ 40

A-3. Water Treated with Different Grades of Magnesium Oxide

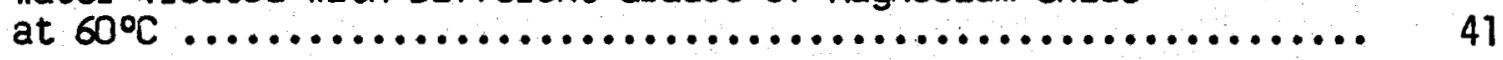

A-4. Water Treated with Remosil at Four Temperatures ............... 42

A-5. Water Treated with Dolomitic Lime and Remosil at Constant

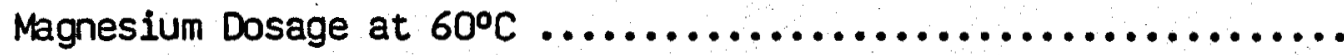

A-6. Water Treated with Remosil at $60^{\circ} \mathrm{C} \ldots \ldots \ldots \ldots \ldots \ldots \ldots \ldots \ldots . . . . . . .43$

A-7. Water Treated with Remosil to Simulate a Two-Stage

Countercurrent Process 
A-8. Water Treated with Carbonated Solutions of Magnesium Oxide at $60^{\circ} \mathrm{C}$

A-9. Water Treated with Magnesium Sulfate (Epsom Salt) at $60^{\circ} \mathrm{C} \ldots \ldots .46$

A-10. Water Treated with Magnesium Sulfate and Soda Ash at $60^{\circ} \mathrm{C} \ldots \ldots .46$

A-11. Water Treated with Equimolar Quantities of Magnesium Sulfate

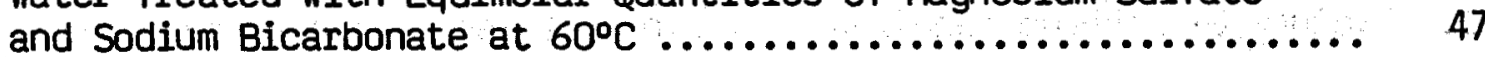

A-12. Water Treated with Magnesium Sulfate at $60^{\circ} \mathrm{C} \ldots \ldots . \ldots . \ldots . . . .47$

A-13. Water Treated with Magnesium Sulfate and Soda Ash at $60^{\circ} \mathrm{C} . . . . . .48$

A-14. Water Treated with Magnesium Chloride at $60^{\circ} \mathrm{C}$ and $\mathrm{pH} 10.2 . . . . . .48$

A-15. Water Treated with Magnesium Chloride at $60^{\circ} \mathrm{C}$ and $\mathrm{pH} 11.2 . . . . . .49$

A-16. Water Treated with Magnesium 0xide Following pH Adjustment

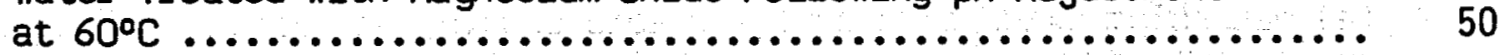

A-17. Water Treated with Ferrous Sulfate at $60^{\circ} \mathrm{C}$ and Varying $\mathrm{pH} . \ldots . .51$

A-18. Water Treated with Ferric Chloride at $60^{\circ} \mathrm{C} \ldots \ldots . . . . . . . . . .65$

A-19. Tabulation of Magnesium Systems at $60^{\circ} \mathrm{C} \ldots \ldots . \ldots . \ldots . . . . . . .62$ 


\section{INTROOUCTION}

The $5 \mathrm{MW}(\mathrm{e})$ Pilot Power Plant at Raft River is of conventional design with cooling provided by evaporation in a cross-flow cooling tower. This plant differs from other conventional power plants by its use of geothermal water as cooling fluid because of restrictions on the consumptive use of cold aquifer or clean surface waters in the Raft River valley.

Raft River geothermal water has a high concentration of silica, a major scale former, and its use requires means to limit silica scaling. Standard procedures nominally employ a process called blowdown, by which build-up of silica and other detrimental substances can be regulated by partial removal and dilution. Also, because cooling is by evaporation, water loss must be supplemented by additional water which, in the present system, would be geothermal water with its attendant high silica concentrations. Additional losses occur from wind blowing a portion of the water mist out of the cooling tower. In steady-state operation, the amount of geothermal water added, termed make-up, is the sum of blowdown, evaporation, and wind losses.

Thus, to use geothermal water as coolant for the $5 \mathrm{MW}(\mathrm{e})$ Pilot Power Plant will require means to effectively control silica levels within both coolant and make-up water.

The ratio of silica concentration in the recirculating coolant to its concentration in the make-up is termed "cycles of concentration." This ratio will always be greater than unity owing to the build-up of silica in the recirculating fluid from evaporation and solubility changes during cooling.

A communication (April 20, 1977) from Betz Laboratories, Inc. 1 stated that it was not possible to control silica scaling by use of dispersants alone and that the best way to handle the problem is to keep 
silica at low concentrations $(<100 \mathrm{ppm})$. Because silica concentrations in Raft River geothermal water range from 160 to $200 \mathrm{ppm}$, use of geothermal water requires that silica concentration be reduced. If the silica content after initial reduction is sufficiently low, some of the costs of this approach can be tempered by use of high cycles of concentration which effectively reduce quantities of make-up required. The volume of make-up required as a function of cycles of concentration has been calculated by Nguyen; ${ }^{2}$ his data are shown in Table 1 and Figure 1.

TABLE 1. MAKE-UP AND BLOWDOWN RATES FOR DIFFERENT CYCLES OF CONCENTRATION

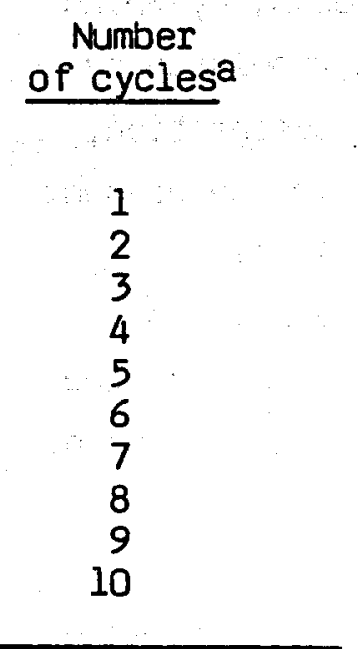

$\mathrm{L} / \mathrm{S}$

38.82
29.11
25.87
24.26
23.28
22.64
22.83
21.83
21.56

Make-up

$\frac{\text { Blowdown rate }}{\mathrm{L} / \mathrm{S} \quad \mathrm{gpm}}$

a. Temperature change is $36 \mathrm{~K}\left(20^{\circ} \mathrm{F}\right)$.

Conventional water-treatment systems use magnesium oxide to remove silica, and lime to control $\mathrm{pH}$. Dolomitic lime is frequently used because it provides both $\mathrm{MgO}$ and $\mathrm{Ca}(\mathrm{OH})_{2}$. This method, using a warm-lime softening unit, was proposed by the Architect-Engineer for the Raft River plant.

This report addresses the problem of removing silica from geothermal water by using the system described above. The Architect-Engineer's recommendation was tested and results conclusively demonstrated it to be totally 


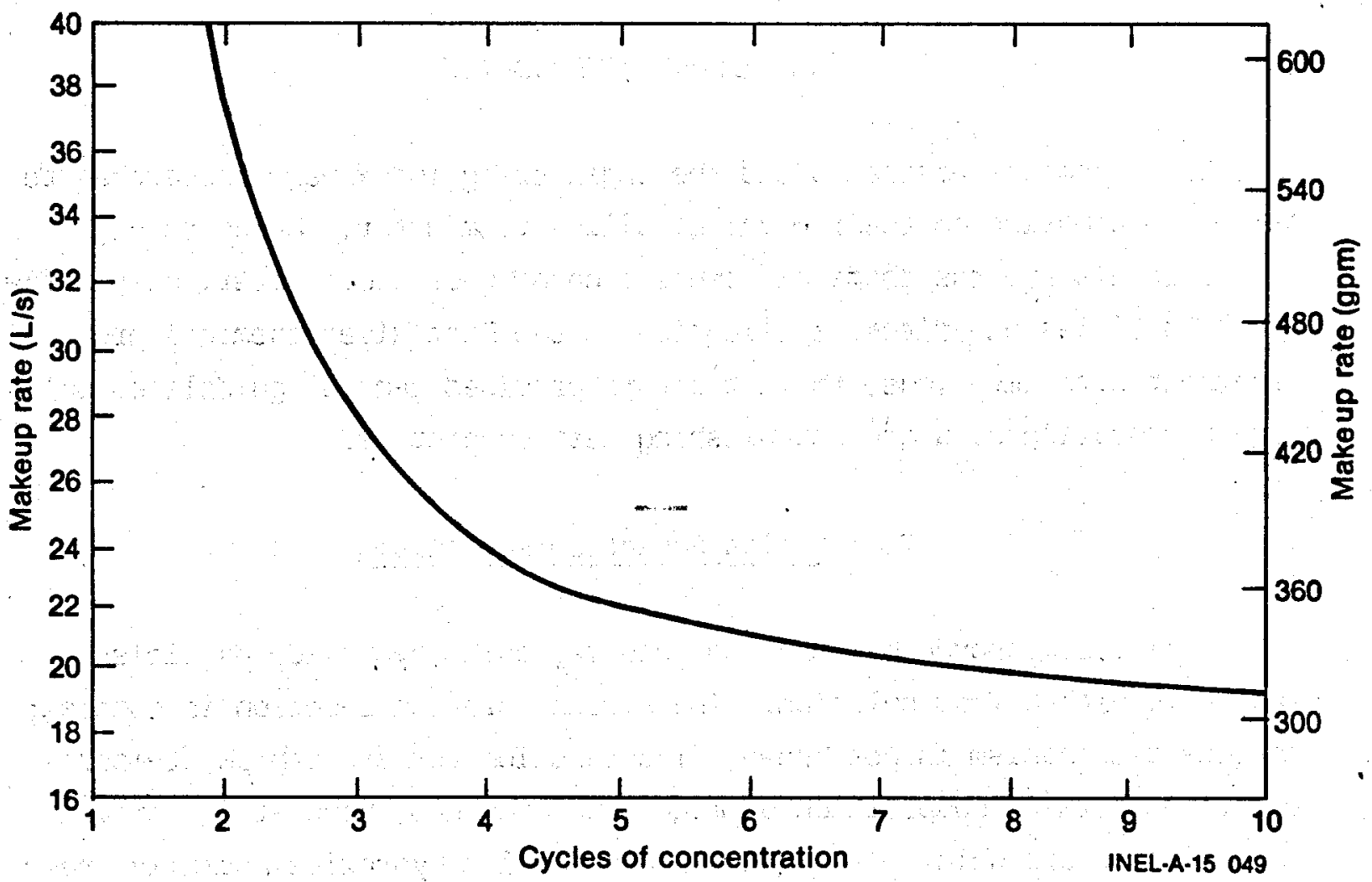

Figure 1. Volume of make-up required at various cycles of concentration.

inadequate. Thereafter, other sorption-based schemes were investigated to determine effective silica removal techniques, especially those which could reduce silica levels to $10-15 \mathrm{ppm}$ and thereby permit five to ten cycles of concentration to be used. 


\section{LITERATURE SEARCH}

Both Chemical Abstracts and the Engineering Index were researched to gather information on the removal of silica from water. Owing to high silica levels and the chemical composition of geothermal water, only a few of the articles had direct application to the Raft River chemical pretreatment program. Thus, the Literature provided general guidelines only for interpreting data and establishing test parameters.

\subsection{Silica Reduction Mechanisms}

Silica is removed by sorption onto magnesium hydroxide particles as they precipitate from solution. The silica sorption reaction is complex; the exact mechanism is not known. The reaction varies with pH, temperature, and form or composition of magnesium compound; however, no silica reduction occurs below the $\mathrm{pH}$ at which magnesium hydroxide normally precipitates. 3

According to Krauskopf, ${ }^{4}$ the silicic acid monomer $\left(\mathrm{H}_{4} \mathrm{SiO}_{4}\right)$ is the dominant species in solution over a $\mathrm{pH}$ range of $0-9$ and has a solubility of 100-140 ppm at $298 \mathrm{~K}$. Above $\mathrm{pH} 9$, the solubility increases as the silicic acid dissociates according to the following equilibrium reactions at $298 \mathrm{~K}$.

$$
\begin{aligned}
& \mathrm{H}_{4} \mathrm{SiO}_{4}=\mathrm{H}_{3} \mathrm{SiO}_{4}^{-1}+\mathrm{H}^{+}, \mathrm{pK}_{1}=9.7 \text { (Ref. 5) } \\
& \mathrm{H}_{3} \mathrm{SiO}_{4}^{-1}=\mathrm{H}_{2} \mathrm{SiO}_{4}^{-2}+\mathrm{H}^{+}, \mathrm{pK}_{2}=11.7 \text { (Ref. 7) } \\
& \mathrm{H}_{2} \mathrm{SiO}_{4}^{-2}=\mathrm{HSiO}_{4}^{-3}+\mathrm{H}^{+}, \mathrm{pK}_{3}=12.0 \text { (Ref. 7) } \\
& \mathrm{HSiO}_{4}^{-3}=\mathrm{SiO}_{4}^{-4}+\mathrm{H}^{+}, \mathrm{pK}_{4}=12.0 \text { (Ref. 7) }
\end{aligned}
$$

By convention the equilibrium constant is 
$K=\frac{\text { concentration of products }}{\text { concentration of reactants }}$

and the $\mathrm{pK}$ term is defined as

$\mathrm{pK}=\log _{10} \frac{1}{\mathrm{~K}}$

For weak acids, at the point where the molar concentrations of the ionic species become equal, the $\mathrm{pK}$ and $\mathrm{pH}$ values coincide. For example, using the equation above, we have

$$
K=\frac{\left[\mathrm{H}_{3} \mathrm{SiO}_{4}^{-1}\right]\left[\mathrm{H}^{+}\right]}{\left[\mathrm{H}_{4} \mathrm{SiO}_{4}\right]}
$$

which reduces to

$K=\left[\mathrm{H}^{+}\right]$

at $\mathrm{pH}=9.7$, since $\left[\mathrm{H}_{4} \mathrm{SiO}_{4}^{-2}\right]$ and $\left[\mathrm{H}_{3} \mathrm{SiO}_{4}^{-1}\right]$ become equal. Thus, $p K=\log _{10} \frac{1}{K}=\log _{10} \frac{1}{\left[H^{+}\right]}=p H=9.7$.

The temperature dependence of the dissociation constants has been determined by Ryzhenko ${ }^{8}$ to be

$\mathrm{pK}_{1}=\frac{3405.9}{T}-6.368+0.0163436 T$

for $T$ varying from 0 to $350^{\circ} \mathrm{C}$,

and

$\mathrm{pK}_{2}=\frac{8949.2}{T}-33.000+0.049580 T$ 
for $T$ varying from 0 to $250^{\circ} \mathrm{C}$.

The first lonized form of silicic acid $\left(\mathrm{H}_{3} \mathrm{SiO}_{4}^{-1}\right)$ is the active species in silica reduction.

\section{2 pH Effect}

Any increase in hydroxide alkalinity above pH 9 will increase the concentration of ionized forms of silicic acid. Therefore, increasing pH should increase silica reduction up to some optimum $\mathrm{pH}$ value. Betz et al. ${ }^{9}$ treated water samples having silica contents varying from 7.1 to $26.2 \mathrm{ppm}$ with magnesium oxide. Their tests covered a pH range of 9.5 to 10.6. They concluded that the optimum pH for silica reduction is 10.1. They also stated that as residual silica in the treated water decreases, control of pH becomes less important.

Wey and Siffert ${ }^{10}$ treated solutions containing $140 \mathrm{ppm}$ silica with equivalent amounts of magnesium chloride and determined that the maximum precipitation of silica occurred in the $\mathrm{pH}$ range 11.0-11.5.

Mujeriego ${ }^{6}$ treated water containing 100 and $140 \mathrm{ppm}$ silica with several metals, including magnesium, and concluded that reaction $\mathrm{pH}$ is the single most important parameter governing silica removal by sorption on all of the hydrous metal oxides studied. He states that in the temperature range from 303 to $313 \mathrm{~K}\left(86-104^{\circ} \mathrm{F}\right)$, the optimum silica removal occurs at a $\mathrm{PH}$ given by the expression

$p H_{\text {optimum }}=\frac{p K_{1}+p K_{2}}{2}$.

\subsection{Effect of Magnesium Type}

\subsubsection{Dolomitic Lime}

The use of dolomitic lime for removal of silica has several advantages. It is inexpensive and provides both magnesium ( 37 weight percent 
$\mathrm{MgO})$ for sllica removal and lime (58 weight percent $\mathrm{Ca}(\mathrm{OH})_{2}$ ) for $\mathrm{pH}$ adjustment.

Behrman and Gustafson ${ }^{11}$ treated identical water samples containing $17 \mathrm{ppm}$ silica as follows: one sample was treated with a high calcium lime, the second with dolomitic lime in the amount required to produce the same quantity of calcium hydroxide as in the first sample. They reported that the concentration of residual silica in both samples was $10 \mathrm{ppm}$ and concluded that (a) dolomitic lime is not effective in reducing silica and (b) magnesium hydroxide to be really effective must be formed in situ.

Betz et al. 9 indicated that dolomitic lime has merit for removal of silica under controlled conditions, although the process alters the water chemistry in such a way as to make the process impractical.

Crossan $^{12}$ treated Mississippi River water with dolomitic lime and found that dolomitic lime (on the basis of equivalent magnesium) was at least one-half as effective as ionic magnesium. For water samples with silica content over $4.5 \mathrm{ppm}$, even better results were obtained.

\subsubsection{Nondissolved Magnesium Compounds}

There are a number of commercially available sources of magnesium. They include soluble salts of magnesium, such as magnesium chloride, and insoluble magnesium compounds, such as dolomitic lime, magnesium carbonate, and various grades of magnesium oxide. The difference between the two forms is that when a soluble magnesium salt is used, the magnesium hydroxide must be generated by a pH adjustment.

\subsubsection{Dissolved Magnesium Compounds (Salts)}

The concept of generating the magnesium hydroxide in situ for increased effectiveness in silica reduction has sound basis in the literature. There is, however, some disagreement as to the actual percentage increase in silica removal attributable to soluble magnesium salts 
over that of insoluble magnesium compounds. The previously noted literature generally concurs with Wohlberg and Buchholz, 13 "... silica in: water is a metastable system whose behavior is difficult to predict." 


\section{DESIGN SPECIFICATIONS}

Facility Systems Engineering Corp. (FSEC) of Los Angeles was selected as the Architect-Engineer for the $5 \mathrm{MW}(\mathrm{e})$ Pilot Power Plant. FSEC (on the recommendation of their consultant, Garrett Energy Research and Development, Inc.) specifled that a conventional warm-lime softener unit would be adequate for water-treatment requirements. A cochrane Warm Process Water Softener Design "UW3" or equivalent, of $21.8 \mathrm{~L} / \mathrm{s}$ (346 gpm) capacity will be the system used for the water pretreatment operation.

Chemical reagents specified include dolomitic lime for both $\mathrm{pH}$ adjustment and silica removal and soda ash for calcium reduction. Design specifications for inlet and outlet water quality are:

\section{Inlet Water Outlet Water}

Total silica, as $\mathrm{SiO}_{2}(\mathrm{ppm})$

Total calcium, as $\mathrm{CaCO}_{3}$ (ppm)

Total bicarbonate, as $\mathrm{CaCO}_{3}$ (ppm)

Total (OH) alkalinity, as $\mathrm{CaCO}_{3}$ (ppm)
180

10-15

93.9

49.8

0
342.8

0

156.9 


\section{EXPERIMENTAL PROCEDURE}

The principal method used to study silica removal was to mix cooled geothermal fluid with chemicals used in the treatment test in amounts and sequence required to form the magnesium silicate-magnesium oxide-calcium hydroxide slurry. Flocculation of precipitated materials was used to simulate typical industrial practice. The apparatus and technique used are described below.

The treated and clarified water fraction of the slurry was analyzed to determine changes in chemical composition. The chemical components (species) determined were silica, $\mathrm{pH}$, calcium concentrations, and alkalinity. Methods used are described below.

\subsection{Jar Tests}

Tests were conducted in accordance with ASTM D-2035-74 (Coagulation-Flocculation Jar Test of Water), ${ }^{14}$ using a Phipps and Bird Model 7790-300 six-paddle stirrer. Test apparatus consisted of a constant temperature bath, six 2-litre beakers, and the Phipps and Bird test stirrer. The beakers, each containing 1.8 litres of geothermal water, were placed in the constant temperature bath and were allowed to come to thermal equilibrium. Chemical reagents, as solutions or slurries, were added to each beaker in the quantities and sequence required for each test. Deionized water was added to bring the total volume in each beaker to two litres. Each system was flash-mixed for one minute by using a paddle velocity of $120 \mathrm{rpm}$, with velocities then reduced to $20 \mathrm{rpm}$ or just rapid enough to keep the resulting floccules in suspension and stirred for fifteen minutes. The beakers were removed from the constant temperature bath and the water samples filtered. The water samples were chemically analyzed for silica, calcium, $\mathrm{pH}$, and alkalinity. Analyses were performed, according to procedures recommended by the Hach Company ${ }^{15}$ for water analysis, using reagents that are marketed commercially. 


\subsection{Chemical Analysis}

Silica concentrations were determined as silicomolybdates, using : a Beckman Model B spectrophotometer. A calibration curve (Figure 2) was generated by using standard solutions of 1 and $10 \mathrm{ppm}$ silica. A sample of untreated water diluted with distilled water, in the ratio of 1 to 25 , gives a percent transmittance between the two standards. The initial silica concentration was then determined and used in subsequent dilutions (2:25, 5:25, etc.). A plot of the $\log$ of percent transmittance versus concentration was then used to determine the silica concentration.

Calcium was determined by titrating $50-\mathrm{cm}^{3}$ samples of treated water with a standard solution of $0.02 \mathrm{~N}$ EDTA. ${ }^{a}$ Alkalinity was determined by titrating $50-\mathrm{cm}^{3}$ samples of treated water with $0.02 \mathrm{~N}$ sulfuric acid. The latter titration was performed by using an automatic titrater to a $\mathrm{pH}$ of 4.8. Calcium concentrations are reported as $\mathrm{ppm} \mathrm{CaCO}_{3}$; alkalinities are reported as $\mathrm{ppm} \mathrm{CaCO}_{3}$.

a. EDTA = (Ethylenedinitrilo) tetraacetic acid or ethylenediaminetetraacetic acid. 


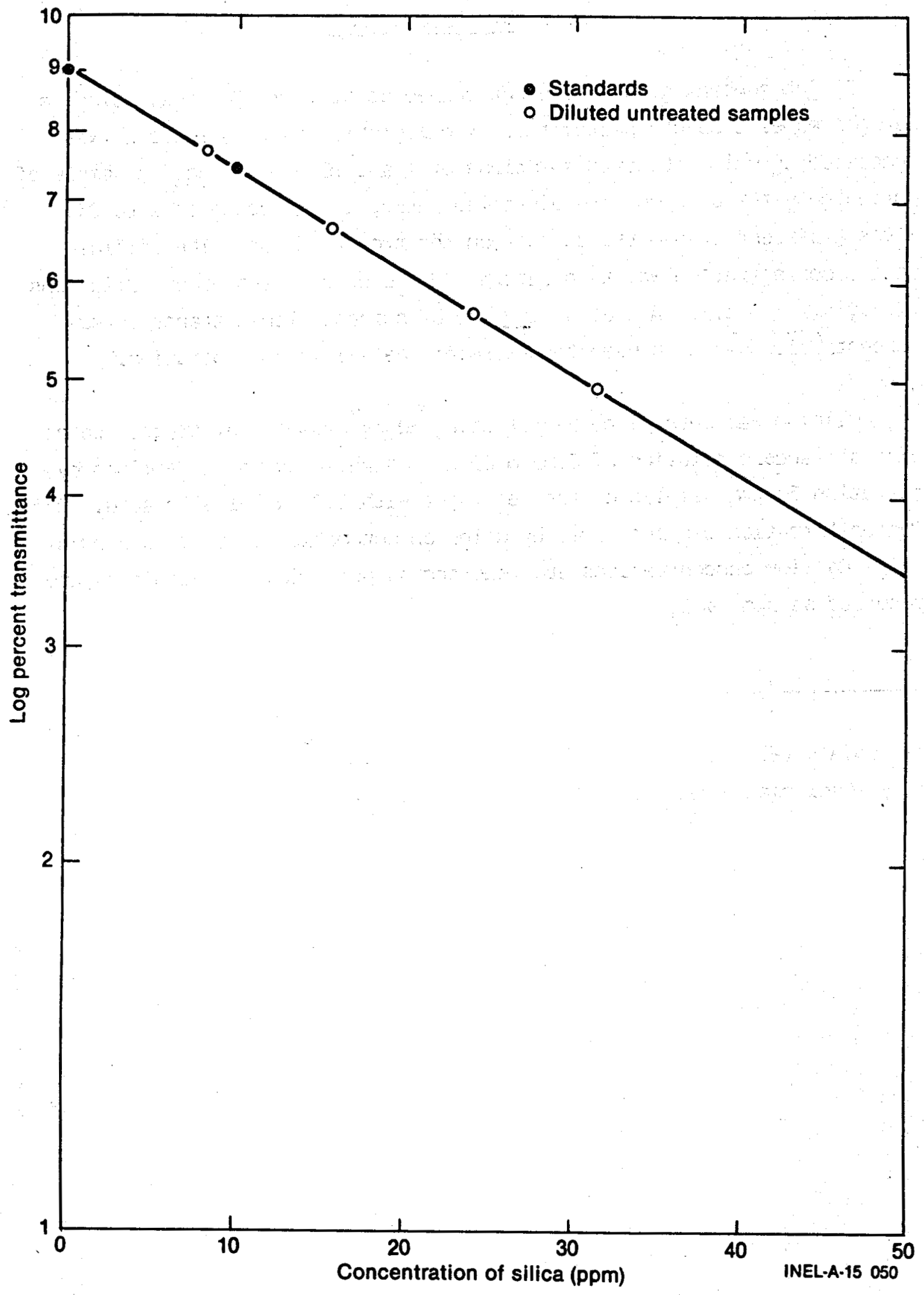

Figure 2. Log percent transmittance versus concentration of silica. 


\section{EVALUATION OF SYSTEM SPECIFIED BY. THE ARCHITECT-ENGINEER}

As noted in section 3, FSEC specified a dolomitic lime treatment system using a conventional warm-lime softener unit for the silica removal operation. This section addresses test results of the above-mentioned system.

\subsection{Dolomitic Lime}

The use of dolomitic lime for silica reduction has the distinct advantage of being an inexpensive source of magnesium. It also contains calcium hydroxide which is used to adjust $\mathrm{pH}$. The disadvantage is that the magnesium oxide concentration cannot be varied without changing the pH. To evaluate dolomitic lime, the concentration in the geothermal fluid was varied from 0 to $1200 \mathrm{ppm}$. Table A-1 summarizes the data with the respective concentrations of magnesium oxide and calcium hydroxide listed as ppm MgO and $\mathrm{CaO}$, respectively.

\subsection{Effect of $\mathrm{pH}$ and Magnesium}

Results (Figure 3) show that silica reduction to desired levels was not achieved, at least in the concentration and $\mathrm{pH}$ range covered. The increase in residual silica at $\mathrm{pH} 11.0$ was unexpected; it had been anticipated that any increase in magnesium would result in some additional silica removed. This increase in residual silica at $\mathrm{pH} 11.0$ was observed in other tests run with dolomitic lime and other forms of magnesium oxide, and it was noted in those tests that a pH of 10.9 or 11.1 was never reached. This would indicate that at $\mathrm{pH} 11.0$ an equilibrium is being established with the silica in solution as a partially soluble complex, or that the magnesium is complexed in some way that makes it unavailable to react with the silica. The decrease in silica above $\mathrm{pH} 11.0$ is attributed to silica precipitation as a calcium compound. 


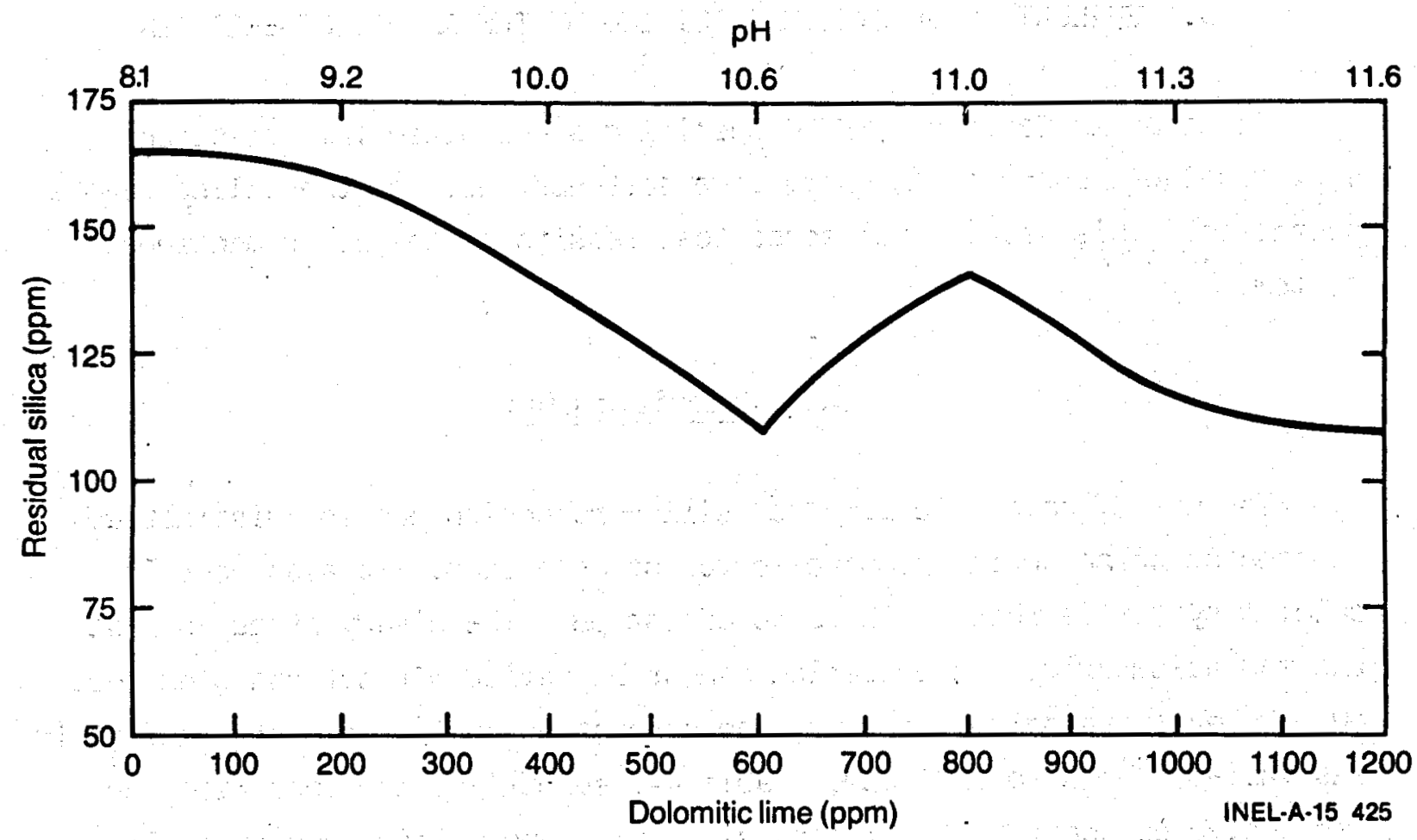

Figure 3. Water treated with 1 ime at $60^{\circ} \mathrm{C}$.

\subsection{Temperature Effect}

Increases in temperature are known to increase the effectiveness of magnesium in reducing silica. If increased temperature resulted in a significant increase in silica reduction, the hot $\left(403 \mathrm{~K}, 266^{\circ} \mathrm{F}\right)$ geothermal water could be mixed with the power plant effluent to raise the temperature prior to its entering the lime softener. Test results show that a temperature increase from 323 to $353 \mathrm{~K}$ ( 50 to $80^{\circ} \mathrm{C}$ ) resulted in an increase in silica removed, from 42 to 55 percent of the initial silica concentration. The lowest residual silica, $65 \mathrm{ppm}$, occurred at a pH of 10.5 and a temperature of $353 \mathrm{~K}\left(80^{\circ} \mathrm{C}\right)$; the highest, $143 \mathrm{ppm}$, at a pH of 10.8 and a temperature of $323 \mathrm{~K}\left(50^{\circ} \mathrm{C}\right)$. Data for the four temperatures $\left(50,60,70\right.$, and $\left.80^{\circ} \mathrm{C}\right)$ evaluated are listed in Table $\mathrm{A}-2$. The magnesium oxide concentrations were held constant at $200 \mathrm{ppm}$ MgO for plant operating economy as well as to reduce the time required for 
testing and chemical analysis. Also, in this test, and many subsequent tests, the pH did not exceed 10.8. It is not economical, on a large scale, to operate in the higher $\mathrm{pH}$ range as this would require additional soda ash for hardness reduction and sulfuric acid for $\mathrm{pH}$ reduction to 6.5 as specified for the recirculating coolant. 


\section{EVALUATION OF MAGNESIUM OXIDE SYSTEMS}

Results of the design basis water-treatment system tests (Tables A-1 to $A-6)$ suggest that additional testing be done to determine what modifications of the chemical pretreatment system would be required to reduce silica concentration to acceptable levels. In this regard, additional systems were investigated to find a pretreatment program capable of producing water of required quality.

\subsection{Effect of Grade of Magnesium Oxide}

Three commercially marketed grades of magnesium oxide (Remosil, ${ }^{a}$ heavy, and light) were obtained to determine what effect the grades of magnesium have on silica reduction. The magnesium oxide concentration was held constant at $200 \mathrm{ppm}$ and the $\mathrm{pH}$ was varied, by lime additions, from 10.2 to 10.8 in each test set.

The Remosil is slightly more efficient in silica removal than either the light or heavy grades of magnesium oxide (Table A-3). The difference between Remosil and heavy grade is only five percent, with a residual silica content of 65 and $74 \mathrm{ppm}$, respectively, at $\mathrm{pH}$ 10.5. Remosil is approximately 20 percent more effective in silica reduction than dolomitic lime at equal magnesium oxide concentration and $\mathrm{pH}$. The heavy and light grades are comparable to each other.

\subsection{Temperature Effect Evaluation Using Remosil}

Remosil was selected for evaluation of the temperature effect, since it was slightly more effective in silica reduction than the light and heavy grades of magnesium oxide (Table A-3). The same test procedure of holding magnesium oxide addition constant and varying $\mathrm{pH}$ by lime addition was followed. The temperature range covered was 323 to $353 \mathrm{~K}$ $\left(50-80^{\circ} \mathrm{C}\right)$.

a. Remosil is a light grade of magnesium oxide marketed by Betz Laboratories. 
Maximum silica reduction occurred at $353 \mathrm{~K}\left(80^{\circ} \mathrm{C}\right)$ and a $\mathrm{pH}$ of 10.2 ; the residual silica was $68 \mathrm{ppm}$ and corresponded to a silica reduction of 56 percent from the untreated water. The minimum silica reduction occurred at $323 \mathrm{~K}\left(50^{\circ} \mathrm{C}\right)$ and a pH of either 10.2 or 10.5 , the residual silica being $138 \mathrm{ppm}$, representing a reduction of only 11 percent. The silica content of the feed water was $155 \mathrm{ppm}$. Data are listed in Table A-4. The most significant feature of the data is the large amount of lime required for $\mathrm{pH}$ adjustment at $353 \mathrm{~K}$, compared to that required at $323 \mathrm{~K}$; the ratio is approximately 3 to.1. A similar observation was seen for dolomitic lime (Table $A-2$ ) and indicates that any increase in silica reduction with increasing temperature would be offset by the cost of additional lime and soda ash required for $\mathrm{pH}$ adjustment and calcium removal.

\subsection{Dolomitic Lime Plus Remosil}

Due to the large amount of $\mathrm{Ca}(\mathrm{OH})_{2}$ in the dolomitic lime, the possibility exists of adjusting $\mathrm{pH}$ with dolomitic lime, and using a second source of magnesium oxide to achieve the desired reduction in silica. Table A-5 shows results of tests for this hypothesis. In these tests, the magnesium oxide concentrations were held constant at $250 \mathrm{ppm}$ and the $\mathrm{pH}$. varied from 10.2 to 10.8 . Test samples 1 and 4,2 and 5,3 and 6 have identical chemical additions. Duplicate tests were run to determine the reproducibility of results.

The lowest residual silica level was $75 \mathrm{ppm}$, indicating that the system will not adequately remove silica. The silica reductions in this test series are within 3 percent of each other. The chemical analysis data indicate that possibly a slight excess of dolomitic lime may have been added to Sample 2. Acceptable levels of sillca could not be achieved when using geothermal fluid, no matter what level of magnesium oxide was used. 


\subsection{High Concentrations of Magnesium Oxide}

A final magnesium oxide test was run at higher magnesium concentrations, to $750 \mathrm{ppm} \mathrm{Mga,} \mathrm{to} \mathrm{determine} \mathrm{what} \mathrm{level} \mathrm{is} \mathrm{required} \mathrm{to} \mathrm{reduce}$ silica to acceptable levels. Data (Table $A-6$ ) show that silica reduction to $73.5 \mathrm{ppm}$ ( 64 percent removal) at a pH 10.2 and magnesium oxide dose of $625 \mathrm{ppm}$ is neither efficient nor economical.

\subsection{Preliminary Conclusions of Magnesium Oxide Systems}

Reduction of silica to required levels cannot be achieved with either dolomitic lime, the various grades of magnesium oxide, or any combinations. This suggests that either further testing be done with other chemical reagents or that the lime softener be increased in size to handle the larger volumes of water required at fewer cycles of concentration than the design basic of ten.

Data indicate that the primary factor affecting silica reduction is the $\mathrm{pH}$ reached with additions of magnesium oxide. The large quantities of magnesium oxide added for water having high silica contents automatically adjusts the $\mathrm{pH}$ to approximately 10.2. At this $\mathrm{pH}$, too little magnesium oxide dissolves for efficient silica sorption. Because the extent of the sorption reaction is dependent on the available surface area of the magnesium hydroxide floccules and because the surface area is pH-dependent, the sorption is $\mathrm{pH}-$ dependent. The result of these interactions is reduced silica removal at high $\mathrm{pH}$ values. 


\section{TWO-STAGE COUNTERCURRENT PROCESS UNIT}

This test was set up to simulate a two-stage countercurrent processing unit to evaluate a change in the mechanical design system. Remosil was selected as the source of magnesium, and hydrated lime was used for pH adjustment. Equal quantities of all reagents were simultaneously added to each beaker at the start of the test. At the end of the test, water samples were filtered into two-litre beakers and returned to the constant temperature bath. Remosil, was then added to each beaker in concentrations varing from 25 to $200 \mathrm{ppm}$. The systems were stirred slowly for 15 minutes, then allowed to settle. Samples were filtered and analyzed for silica.

Data (Table A-7) show that a two-stage countercurrent process unit would adequately reduce silica concentration. The addition of $400 \mathrm{ppm} \mathrm{MgO}$ in two stages reduces silica to $22 \mathrm{ppm}$ and thereby allows 4.6 cycles of concentration of the recirculating coolant. Thus, in a continuous flow processing system silica reduction is enhanced. 


\section{SOLLBLE MAGNESIUM COMPOUND SYSTEMS}

\subsection{Magnesium Bicarbonate}

The decision to evaluate a magnesium bicarbonate system was the result of a conversation with Mr. A. B. Mindler of Permutit who indicated that prior to 1940 it was standard practice to bubble carbon dioxide through a magnesium hydroxide slurry prior to addition to the softener unit, to enhance silica removal. This agrees with the preliminary indications that the magnesium should be added in ionic form. To evaluate this hypothesis, four samples of ten grams per litre of magnesium oxide slurry were prepared. These systems used the light, heavy, Remosil, and dolomitic lime forms of magnesium oxide. Carbon dioxide was bubbled through each of these systems until no further $\mathrm{pH}$ change was observed over a fifteen-minute period. The light, heavy, and Remosil magnesium oxide systems stabilized at $\mathrm{pH} 6.9$, and all were clear solutions. The dolomitic lime system reached a constant $\mathrm{pH}$ value of 7.1. This system resulted in a clear solution above a deep bed of precipitate.

Samples from each system were filtered and analyzed for magnesium to determine the amount of magnesium dissolved. Data are shown in Table 2.

TABLE 2. ANALYSIS OF FILTERED SAMPLES OF MAGNESIUM HYDROXIDE SLURRIES AFTER BUBBLING CARBON DIOXIDE TO CONSTANT pH

\begin{tabular}{|c|c|c|}
\hline Magnesium Source & $\begin{array}{c}\mathrm{pH} \text { After } \\
\infty_{2}^{\text {Bubbling }}\end{array}$ & $\begin{array}{l}\text { \% Dissolved } \\
\text { Magnesium in } \\
\text { Samples }\end{array}$ \\
\hline 1. Light magnesium oxide system & 6.9 & 100 \\
\hline 2. Heavy magnesium oxide system & 6.9 & 89 \\
\hline 3. Remosil magnesium oxide system & 6.9 & 81 \\
\hline 4. Dolomitic lime magnesium oxide system & 7.1 & 100 \\
\hline
\end{tabular}


The dolomitic lime system was analyzed for calcium and was found to contain less than 0.06 percent in solution, indicating that the precipitate was calcium carbonate.

Two additional jar tests were run with each of the four bicarbonate systems in which the magnesium oxide dosage was held constant and the $\mathrm{pH}$ varied from 10.2 to 10.8 . The $200 \mathrm{ppm}$ magnesium oxide added is based on magnesium in solution, as determined from data of Table 2.

Results indicate that silica reduction using magnesium bicarbonate is a significant improvement over the corresponding magnesium oxide systems. Residual silica concentrations indicate that all four systems are equivalent in silica removal efficiency (variations only to six percent) as shown in Table $A-8$. The best silica reductions occurred at pH 10.2. The small differences in silica reduction at different $\mathrm{pH}$ values indicate little, if any dependence on pH when large amounts of the initial silica are removed.

\subsection{Magnesium Sulfate}

Based on improved silica reduction with magnesium bicarbonate, five additional tests were run, to evaluate magnesium sulfate for silica removal. Five magnesium sulfate systems were evaluated. The first three tests used Epsom salt $\left(\mathrm{MgSO}_{4} \cdot \mathrm{HH}_{2} \mathrm{O}\right)$ as the source of magnesium. The variable in these three tests was the amount of carbonate added as sodium bicarbonate, $\mathrm{NaHCO}_{3}$. Sodium bicarbonate, rather than sodium carbonate, was added, prior to magnesium oxide addition, to maintain a low pH of 8. Data and systems used are listed in Tables A-9, A-10, and A-11.

Results are shown in Figure 4. Maximum silica reduction is achieved when no soda ash is added. The least silica is removed with the magnesium sulfate-sodium bicarbonate system, in agreement with Mujeriego ${ }^{6}$ who found that increased alkalinity had a detrimental effect. 


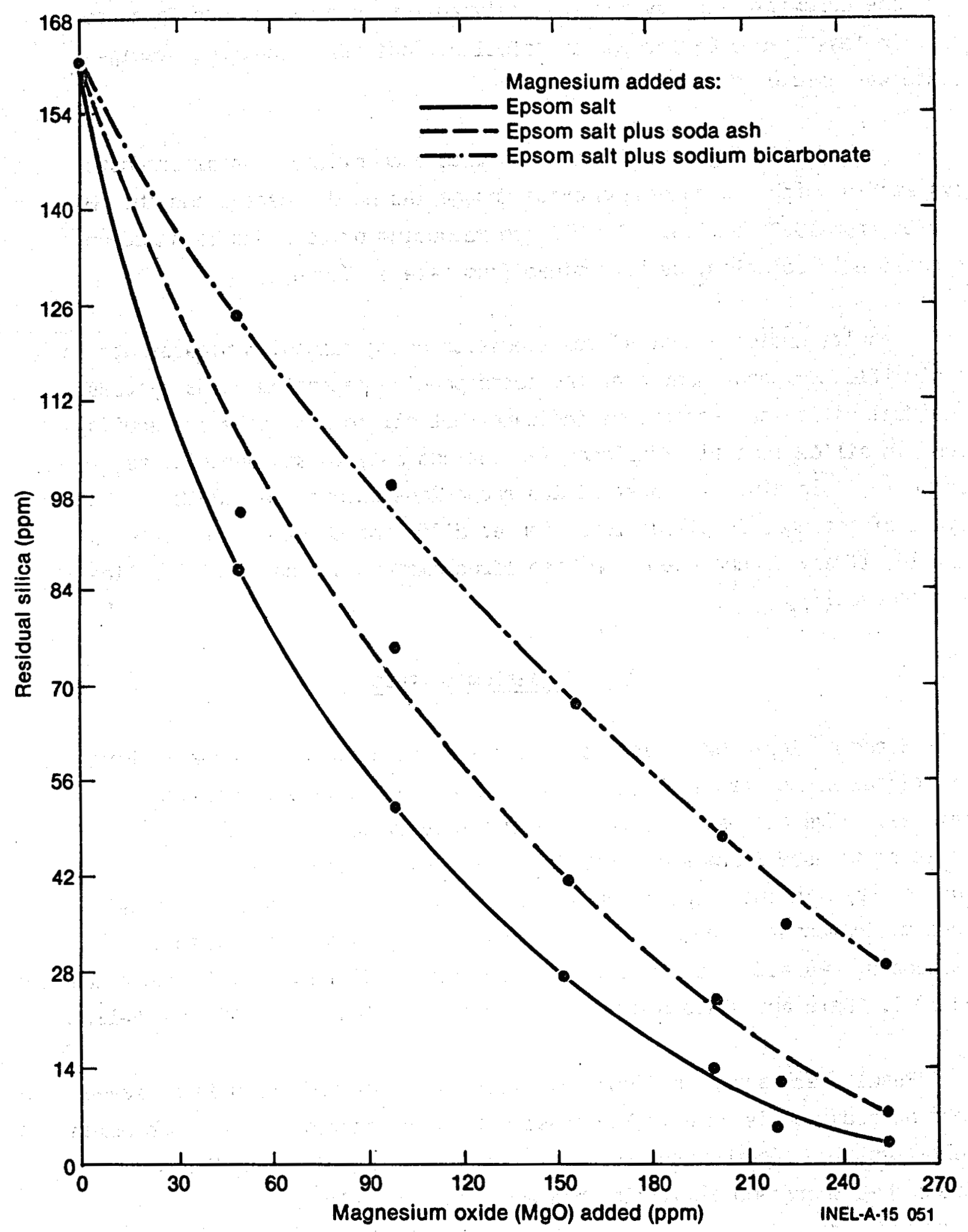

Figure 4. Concentration of residual silica versus concentration of magnesium added as (a) Epsom salt, (b) Epsom salt plus soda ash, and (c) Epsom salt plus sodium bicarbonate. 


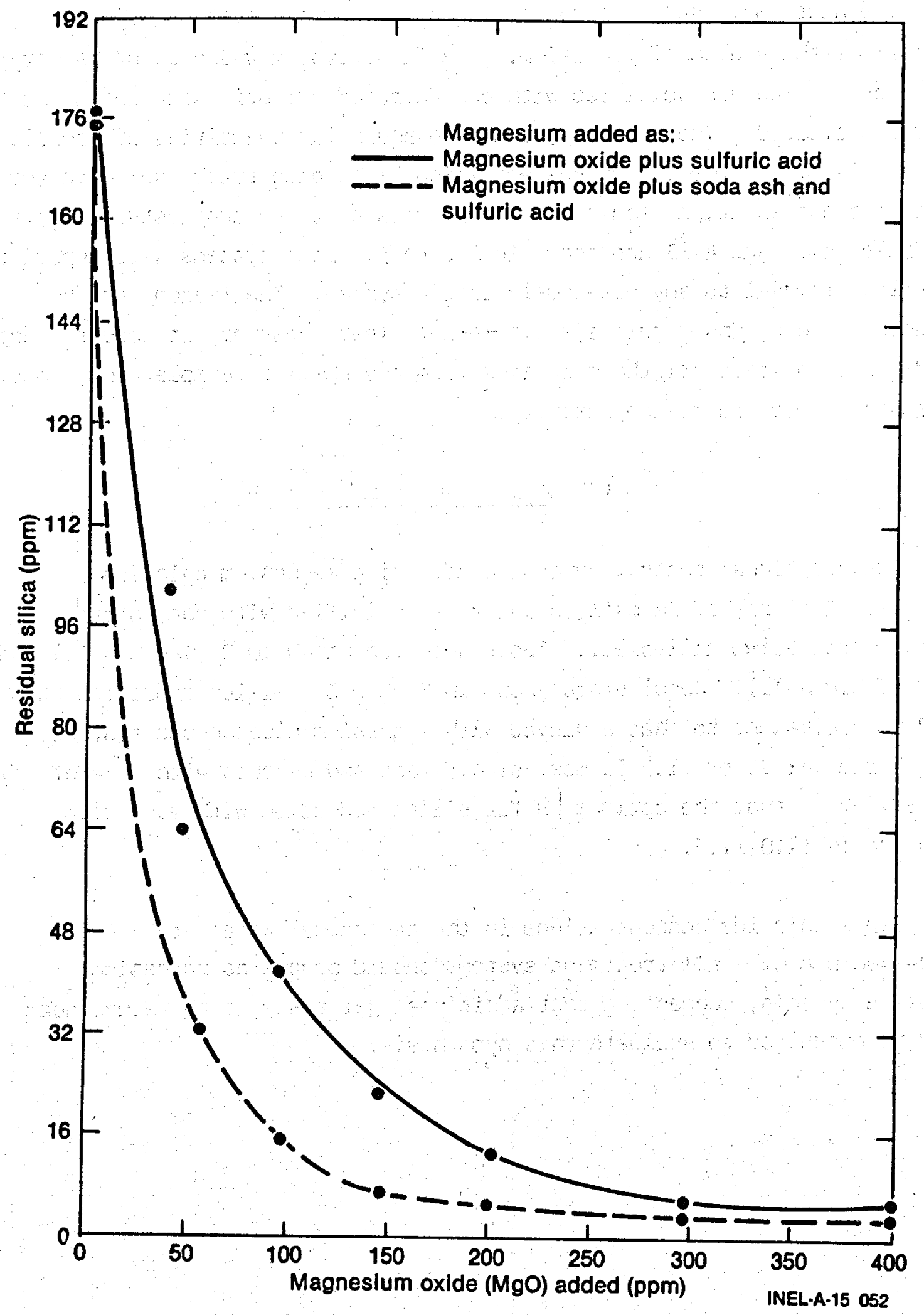

Figure 5. Concentration of residual silica versus concentration of (a) magnesium oxide plus sulfuric acid and (b) magnesium oxide plus soda ash and sulfuric acid. 
The next two tests were run as magnesium sulfate systems using Remosil as the source of magnesium. The first system was a $10 \mathrm{~g} / \mathrm{L}$ slurry of Remosil which was acidified with concentrated sulfuric acid until the solution cleared. The second system used equimolar quantities of Remosil and soda ash, and the slurry was acidified with concentrated sulfuric acid until a clear solution resulted. The results of these two tests are given in Tables $A-12$ and $A-13$ and shown in Figure 5. Both systems were superior in silica removal to any previously tested system. The reason for the enhancement over Epsom salt systems is not clear; however, it appears that acidification frees all the magnesium from any chemical complex and, thus, increases silica-reduction activity.

\subsection{Magnesium Chloride}

Two additional tests were conducted, using magnesium chloride systems. A slurry of Remosil in water was acidified with concentrated hydrochloric acid until clear. Tests were run at $\mathrm{pH} 10.2$ (Table A-14) and 11.2 (Table A-15). Results are shown in Figure 6 . Silica reduction at $\mathrm{pH}$ 10.2 is equivalent to that achieved with magnesium bicarbonate systems. Silica removal at $\mathrm{pH} 11.2$ is most significant and concurs with data of Wey and Siffert ${ }^{10}$ that the optimum $\mathrm{pH}$ for silica reduction with magnesium chloride is $11.0-11.5$.

Since chloride concentrations in the geothermal water are 1000-1400 ppm Cl${ }^{-}$, all treatment systems should behave as magnesium chloride systems, suggesting that additional jar tests at $\mathrm{pH}$ values near 11.2 be conducted to evaluate this hypothesis. 


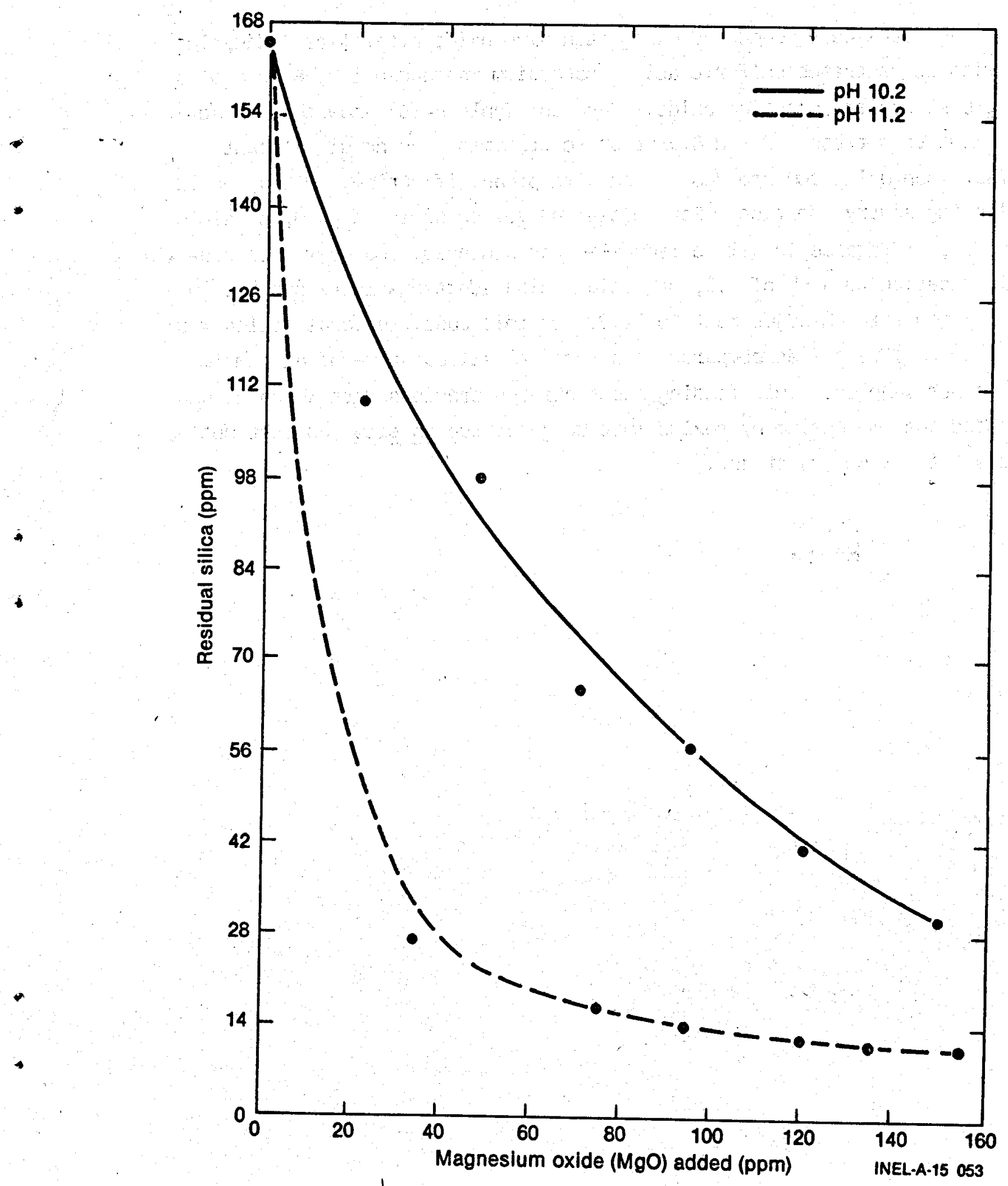

Figure 6 . Concentration of residual silica versus concentration of magnesium oxide plus hydrochloric acid at fixed pH. 


\section{PREACIDIFICATION}

Jar tests were conducted using magnesium oxide after first adjusting $\mathrm{pH}$ with concentrated sulfuric acid. Magnesium was added in the form of a $10 \mathrm{~g} / \mathrm{L}$ slurry of magnesium oxide. Results (Table A-16) show that $\mathrm{pH}$ adjustment to between 6.2 and 8.3 prior to treatment had no significant effect when using $200 \mathrm{ppm}$ MgO. Even with preacidification, $\mathrm{pH}$ reached 10 following slurry addition. For initial pH values as low as 4.0 , no significant difference in silica reduction was" achieved. However, for preacidification to a pH of 3.0, magnesium oxide additions increased the $\mathrm{pH}$ to 3.8 and with $\mathrm{pH}$ adjustment to 10.2 . In this case, residual silica was reduced to $17.6 \mathrm{ppm}$ as compared to a residual silica value of $82 \mathrm{ppm}$ in the other samples. This finding substantiated previous data which demonstrated that magnesium hydroxide must be generated in situ and must not be the agent for $\mathrm{pH}$ adjustment. 
10. IRON SYSTEMS

The use of iron as a silica removal agent was previously demonstrated by Leaf. 16 Two tests were run using iron salts to reduce silica. These tests used $\mathrm{Fe}$ (II) in the form of ferrous sulfate $\left(\mathrm{FeSO}_{4}\right)$ and $\mathrm{Fe}$ (III) in the form of ferric chloride $\left(\mathrm{FeCl}_{3}\right)$. Table A-17 shows results using $\mathrm{FeSO}_{4}$ as the source of iron. The silica was reduced from 185 to $27 \mathrm{ppm}$ $\mathrm{SiO}_{2}$ with $250 \mathrm{ppm} \mathrm{Fe}$ (II) at $\mathrm{pH} 8.6$ with no significant increase at higher $\mathrm{pH}$ values. Table $\mathrm{A}-18$ shows silica reduction using ferric chloride $\left(\mathrm{FeCl}_{3}\right)$ as the source of $\mathrm{Fe}$ (III). These data show that iron will adequately reduce silica levels to the $15-20 \mathrm{ppm} \cdot \mathrm{SiO}_{2}$ range when using approximately $180 \mathrm{ppm} F \mathrm{Fe}$ (III). The primary difference between magnesium and $\mathrm{Fe}$ (III) is that iron reduces the $\mathrm{pH}$ to about 2.4. This eliminates the use of soda ash for calcium removal and dictates the use of sodium hydroxide rather than the less expensive lime for pH adjustment. 


\section{DISCUSSION OF RESULTS}

Various grades of magnesium oxide and dolomitic lime will adequately reduce silica if carbon dioxide is bubbled through the magnesium slurries to a pH of 7. Dolomitic lime, in this type of system, poses a huge sludge problem. Each 100 lb of dolomitic lime used will produce $78 \mathrm{lb}$ of calcium carbonate in the chemical feed tank. Also, there is a large capital investment for carbon dioxide production. The magnesium oxide systems will not produce sludge, but they require carbon dioxide. The initial capital investment to purchase a carbon dioxide generation unit which will produce $91 \mathrm{~kg}(2000 \mathrm{lb})$ of carbon dioxide per day (the requirement for the $5 \mathrm{MW}(\mathrm{e}$ ) Pilot Power Plant) is estimated at $\$ 150,000$. The cost of using liquid carbon dioxide stored in an on-site tank holding $2730 \mathrm{~kg}$ (30 tons) is $\$ 2,200$ per month (at early 1979 prices).

Both magnesium sulfate and magnesium chloride will reduce silica concentration to acceptable levels. The use of magnesium salts will increase total dissolved solids and may reduce the number of cycles of concentration achievable in the recirculating coolant. The increased sulfate from the magnesium sulfate presents a potential gypsum scaling problem on the tubes in the condenser. The excess chloride, from magnesium chloride addition, may not only reduce cycles of concentration in the system, but may significantly increase the corrosion rate, particularly pitting of the condenser tubes, thereby effectively reducing the service lifetime of the condenser.

Other magnesium oxide systems tested were preacidification of make-up water with sulfuric acid prior to addition of a magnesium oxide slurry.

Two iron systems were also tested: $\mathrm{Fe}$ (II) from ferrous sulfate and $\mathrm{Fe}$ (III) from ferric chloride. These iron systems pose the same scaling and corrosion problems as their corresponding magnesium systems. They may, however, be more economical. Ferric chloride differs slightly from magnesium chloride in that sodium hydroxide rather than lime is used to adjust $\mathrm{pH}$. The problem with this system is its inability to reduce the calcium concentrations with soda ash. 
The use of any chemical systems to reduce silica to acceptable levels in the make-up water will naturally create significant changes in the originally anticipated water chemistry of the cooling tower-condenser system. The effect of these chemical changes must be evaluated and integrated with demands of recirculating and blowdown treatment systems before sound recommendations for pretreatment can be made. 


\section{CONCLUSIONS AND RECOMMENDATIONS}

Analyses of water treatment systems tested lead to the following conclusions.

(1) The design specification of 10-15 ppm silica in the effluent water from the pretreatment system cannot be achieved by the use of dolomitic lime, nor with any of the other conventional water-treatment systems simulated in the tests reported here.

(2) The 10-15 ppm residual silica level can be achieved with either a soluble magnesium or iron salt system, where the metal is added as a solution.

(3) The zero-level bicarbonate is automatically met with $\mathrm{pH}$ adjustment.

(4) The maximum calcium concentration of $340 \mathrm{ppm}$ as $\mathrm{CaCO}_{3}$ is readily achieved through the addition of soda ash.

(5) The hydroxide concentration, reported as $\mathrm{CaCO}_{3}$, is in the 150-250 ppm range, slightly higher than the $157 \mathrm{ppm}$ specified.

Recommendations are:

(1) That dolomitic lime should not be used as the source of magnesium for silica reduction, and

(2) That no specific chemical system can be recommended based on the data reported here.

Several systems can adequately reduce silica, yet each of these systems poses potential problems which have yet to be evaluated. 
It is recommended that the chemicals which reduce silica to required levels be tested and evaluated for scaling effects and corrosion rates on carbon steel.

Chemicals recommended for testing for scaling and corrosion on carbon steel after silica removal are $\mathrm{Mg}\left(\mathrm{HCO}_{3}\right)_{2}, \mathrm{MgSO}_{4}$, and $\mathrm{MgCl}_{2}$. Data in Table A-19 show that these systems are effective in silica removal and also have a low ratio of $\mathrm{MgO}$ to $\mathrm{SiO}_{2}$ removed. The most effective treatment is the $\mathrm{MgO} / \mathrm{Na}_{2} \mathrm{CO}_{3} / \mathrm{H}_{2} \mathrm{SO}_{4}$ system; however, it is not considered economical and would substantially increase the solids content. Because of the common anions $\left(\mathrm{Cl}^{-}\right.$, $\mathrm{SO}_{4}^{-2}$ ) of the iron systems, evaluation of the magnesium systems should be indicative of how the iron salt systems would behave with respect to scaling. However, for data confirmation, tests to determine chemical loss and corrosion rates on low-carbon steel using water treated with ferric chloride also should be conducted. 


\section{REFERENCES}

1. R. N. Wallace, private communication, Betz Laboratories, Inc., April 1977.

2. V. Thanh Nguyen, Raft River Thermal Loop Design of the Cooling Water Treatment Plant Using Geothermal Water Supply, Garrett Energy Research and Engineering, Inc., August 15, 1977. Reviewed and updated February 17,1978 , by L...E. Hiebert.

3. L. B. Owen, Precipitation of Amorphous Silica from High-Temperature Hypersaline Geothermal Brines, Lawrence Livermore Laboratory, University of California, M.S. dated 1975.

4. B. K. Krauskopf, "Dissolution and Precipitation of Silica at Low Temperatures," Geochimica et Cosmochimica Acta, 10, 1956, pp. 1-26.

5. S. A. Greenberg and E. W. Price, "The Solubility of Silica in Solutions of Electrolytes," Journal of Physical Chemistry, 61, 11, 1957, pp. 1539-1540.

6. Rafael Mujeriego, Silica Removal from Industrial Water, University Microfilms International, Ann Arbor, Michigan, Ph. D. thesis, University of California, Berkeley, 1976.

7. Handbook of Chemistry and Physics, 53rd edition, Cleveland: Chemical Rubber Publishing Company, 1971.

8. B. N. Ryzhenko, "Determination of Hydrolysis of Sodium Silicate and Calculation of Dissociation Constants of Orthosilicic Acid at Elevated Temperatures," Geochemistry International, 4, 1967, pp. 99-107. 
9. L. D. Betz, C. A. No 11, and J. J. Maguire, "Adsorption of Soluble Silica from Water," Industrial and Engineering Chemistry, 33, 6, 1941, pp. 814-821.

11. R. Wey and B. Siffert, Col. of Intern, Centre Nat'l Rech. Sci. (Paris) No. 115, 1962, pp. 11-23.

11. A. S. Behrman and H. Gustafson, "Removal of Silica from Water," Industrial and Engineering Chemistry, April 1941, pp. 468-472.

12. H. L. Tiger, "Silica Removal by an Improved Magnesia Process,"

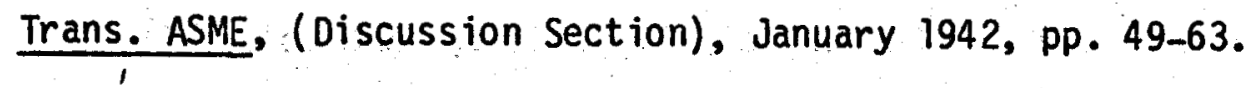

13. Cornel Wohlberg and Jerry R. Buchholz, "Silica in Water in Relation to Cooling Tower Operation," Paper No. 143, Corrosion 75, Toronto, Apri1 14-18, 1975.

14. Annual Book of ASTM Standards, Part 31, Philadelphia: American Society for Testing and Materials, 1978, pp. 1172-1176.

15. Hach Manual for Water and Waste Water Analysis, 3rd edition, Ames, Iowa: Hach Chemical Company, 1975, pp. 2-5, 2-48, and 2-119.

16. Walter B. Leaf, "Silica Removal with Iron Shavings," Journal of the American Water Works Association, September 1948, pp. 981-988.

L. D. Betz, C. A. No 11, and J. J. Maguire, "Removal of Silica from Water by Cold Process," Industrial and Engineering Chemistry, 32, 11, 1941 , pp. 1321-1323.

L. D. Betz, C. A. No11, and J. J. Maguire, "Removal of Silica from Water by Hot Process, "Industrial and Engineering Chemistry, 32, 11 , 1941, pp. $1323-1329$. 
Betz Handbook of Industrial Water Conditioning, 7th edition, Trevose, Pennsylvania: Betz Laboratories, Inc., 1976.

R. N. Wallace, private communication, Betz Industries, Inc., July 1978.

Nordell Eskel, Water Treatment for Industrial and Other Uses, New York: Reinhold Publishing Corporation, 1961.

Ghanshyam 0. Sharma, "Influence of $\mathrm{CO}_{2}$ on Silica in Solution," Geochemical Journal, 3, 1970, pp. 213-227.

G. B. Alexander, W. M. Heston, and R. K. Iler, "The Solubility of Amorphous Silica in Water," Journal of Physical Chemistry, 58, 6, 1954, pp. 453-455.

K. B. Krauskopf, The Geochemistry of Silica in Sedimentary Environments, Special Publication of Society of Economic Paleontologists and Mineralogists Symposium, 7, pp. 4-19.

R. K. Iller, The Colloid Chemistry of Silica and Silicates, New York: Cornell University Press, 1955 .

A. V. Karyakin, Yu B. Kholina, and N. V. Soboleva, "The Interaction of Water with Silica," Geochemistry International, 1975, pp. 176-178.

G. B. Alexander, "The Reaction of Low Molecular Weight Silicic Acids with Molybdic Acid," Journal of the American Chemical Society, 75, 1953, pp. 5655-5657.

R. M. Garrels, "Silica: Role in the Buffering of Natural Waters," Science, 148, April 1965, p. 69.

G. O. Okamoto, Okura Takeshi, and Gota Katsumi, "Properties of Silica in Water," Ceochimica et Cosmochimica Acta, 12, 1957, pp. 123-132. 
G. R. Bell, J. P. Leineweber, and J. C. Yang, Characterization and Removal of Silica from Webster, South Dakota and Roswell, New Mexico Well Waters, United States Department of Interior, Contract No. 14-01-0001-854, Research and Development Progress Report No. 286, January 1968.

John E. Schenk and Walter J. Weber, Jr., "Chemical Interactions of Dissolved Silica with Iron(II) and (III)," Journal of the American Water Works Association, February 1968, pp. 199-212. 



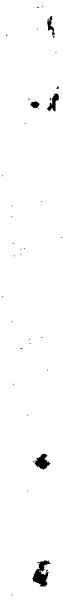

APPENDIX A

ANALYSIS OF WATER TREATED WITH VARIOUS SYSTEMS 
TABLE A-l. WATER TREATED WITH DOLOMITIC LIMEa AT $60^{\circ} \mathrm{C}$

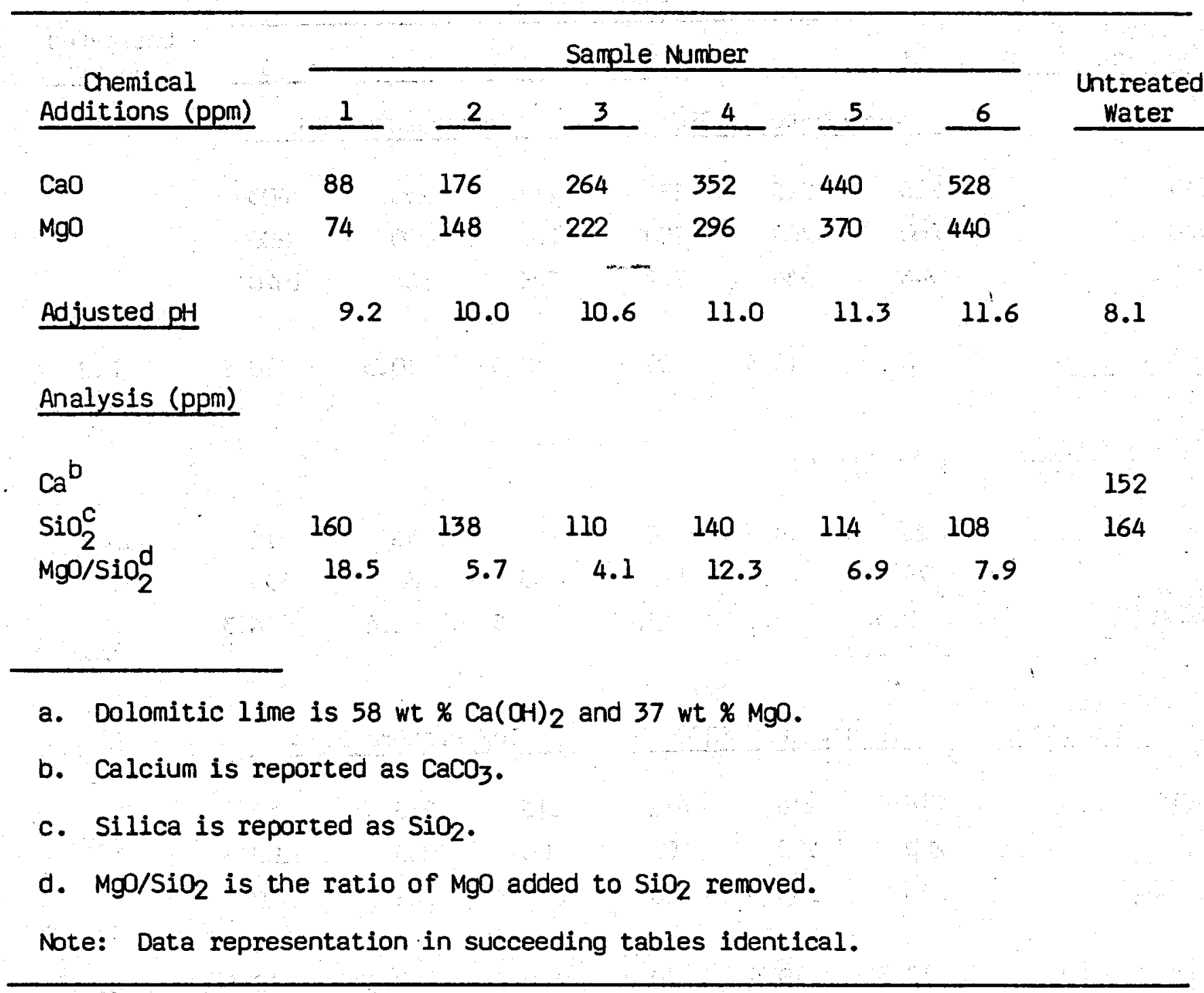


TABLE A-2. WATER TREATED WITH DOLOMITIC LIME AT FOUR TEMPERATURES

\begin{tabular}{|c|c|c|c|c|c|c|c|}
\hline \multirow[b]{2}{*}{$\begin{array}{c}\text { Chemical } \\
\text { Additions (ppm) }\end{array}$} & \multicolumn{6}{|c|}{ Sample Number } & \multirow[b]{2}{*}{$\begin{array}{c}\text { Untreated } \\
\text { Water }\end{array}$} \\
\hline & 1 & 2 & 3 & 4 & 5 & 6 & \\
\hline & \multicolumn{3}{|c|}{ Temperature $80^{\circ} \mathrm{C}$} & \multicolumn{3}{|c|}{ Temperature $70^{\circ} \mathrm{C}$} & \\
\hline $\mathrm{CaO}$ & 216 & 216 & 682 & 216 & 250 & 603 & \\
\hline MgO & 200 & 200 & 200 & 200 & 200 & 200 & \\
\hline $\mathrm{Na}_{2} \mathrm{CO}_{3}$ & 346 & 346 & 792 & 346 & 384 & 1020 & \\
\hline Adjusted pH & 10.5 & 10.5 & 10.8 & 10.5 & 10.5 & 10.8 & 8.2 \\
\hline \multicolumn{8}{|l|}{ Analysis (ppm) } \\
\hline $\mathrm{Ca}$ & 26 & 8 & 6 & 8 & 36 & 12 & 113 \\
\hline $\mathrm{SiO}_{2}$ & 79 & 75 & 113 & 85 & 81 & 133 & 165 \\
\hline $\mathrm{MgO} / \mathrm{SiO}_{2}$ & 2.3 & 2.2 & 3.9 & 2.5 & 2.4 & 6.3 & \\
\hline $\begin{array}{l}\text { Chemical } \\
\text { Additions (ppm) }\end{array}$ & \multicolumn{3}{|c|}{ Temperature $60^{\circ} \mathrm{C}$} & \multicolumn{3}{|c|}{ Temperature $50^{\circ} \mathrm{C}$} & \\
\hline $\mathrm{CaO}$ & 216 & 216 & 412 & 216 & 216 & 450 & \\
\hline MgO & 200 & 200 & 200 & 200 & 200 & 200 & \\
\hline $\mathrm{Na}_{2} \mathrm{CO}_{3}$ & 346 & 346 & 660 & 346 & 346 & 560 & \\
\hline Adjusted pH & 10.5 & 10.5 & 10.8 & 10.6 & 10.6 & 10.8 & 8.2 \\
\hline \multicolumn{8}{|l|}{ Analysis (ppm) } \\
\hline $\mathrm{Ca}$ & 56 & 44 & 10 & 8 & 12 & 10 & 113 \\
\hline $\mathrm{SiO}_{2}$ & 103 & 96 & 113 & 130 & 123 & 143 & 165 \\
\hline $\mathrm{MgO} / \mathrm{SiO}_{2}$ & 3.2 & 2.9 & 3.9 & 5.7 & 4.8 & 9.1 & \\
\hline
\end{tabular}


TABLE A-3. WATER TREATED WITH DIFFERENT GRADES

OF MAGNESIUM OXIDE AT $60^{\circ} \mathrm{C}$

Sample Number

\begin{tabular}{|c|c|c|c|c|c|c|}
\hline $\begin{array}{c}\text { Chemical } \\
\text { Additions (ppm) }\end{array}$ & $1^{a}$ & $2^{a}$ & $3^{a}$ & $4^{b}$ & $5^{b}$ & $6^{b}$ \\
\hline $\mathrm{CaO}$ & 200 & 370 & 400 & 284 & 321 & 435 \\
\hline $\mathrm{MgO}$ & 200 & 200 & 200 & 200 & 200 & 200 \\
\hline $\mathrm{Na}_{2} \mathrm{CO}_{3}$ & 180 & 540 & 510 & 235 & 265 & 355 \\
\hline
\end{tabular}

Untreated

Water

Adjusted $\mathrm{pH}$

$10.2 \quad 10.5$

$10.8^{-\cdots}$

10.2

10.5

10.8

8.1

Analysis (ppm)

$\begin{array}{lccccccc}\mathrm{Ca} & 4 & 6 & 6 & 4 & 14 & 12 & 113 \\ \mathrm{SiO}_{2} & 68 & 65 & 66 & 78 & 74 & 68 & 176 \\ \mathrm{MgO} / \mathrm{SiO}_{2} & 1.9 & 1.8 & 1.8 & 2.0 & 2.0 & 1.9 & \end{array}$

Chemical Additions (ppm)

CaO

$\mathrm{MgO}$

$\mathrm{Na}_{2} \mathrm{CO}_{3}$

$\begin{array}{llllll}\frac{7^{c}}{152} & \frac{8^{c}}{208} & \frac{9^{c}}{380} & \frac{10^{d}}{387} & \frac{11^{d}}{537} & \frac{12^{d}}{637} \\ 200 & 200 & 200 & 200 & 200 & 200 \\ 125 & 170 & 310 & 145 & 285 & 375\end{array}$

Untreated

Water

Adjusted $\mathrm{pH}$

$10.2 \quad 10.5$

10.8

10.2

$10.5 \quad 10.8$

8.1

Analysis (ppm)

$\begin{array}{lccccccc}\mathrm{Ca} & 6 & 6 & 4 & 6 & 4 & 16 & 113 \\ \mathrm{SiO}_{2} & 76 & 81 & 73 & 92 & 88 & 90 & 176 \\ {\mathrm{MgO} / \mathrm{SiO}_{2}} & 2.0 & 2.1 & 1.9 & 2.7 & 2.9 & 2.9 & \end{array}$
a. As Remosil.
b. As heavy grade.
c. As light grade.
d. As dolomitic lime. 
TABLE A-4. WATER TREATED WITH REMOSIL AT FOUR TEMPERATURES

\begin{tabular}{|c|c|c|c|c|c|c|c|}
\hline \multirow{2}{*}{$\begin{array}{l}\text { Chemical } \\
\text { Additions (ppm) }\end{array}$} & \multicolumn{6}{|c|}{ Sample Number } & \multirow[b]{2}{*}{$\begin{array}{c}\text { Untreated } \\
\text { Water }\end{array}$} \\
\hline & 1 & 2 & 3 & 4 & 5 & 6 & \\
\hline & \multicolumn{3}{|c|}{ Temperature $80^{\circ} \mathrm{C}$} & \multicolumn{3}{|c|}{ Temperature $70^{\circ} \mathrm{C}$} & \\
\hline $\mathrm{CaO}$ & 483 & 920 & 1320 & 189 & 265 & 605 & \\
\hline MgO & 200 & 200 & 200 & 200 & 200 & 200 & \\
\hline $\mathrm{Na}_{2} \mathrm{CO}_{3}$ & 600 & 1070 & 1600 & 208 & 288 & 774 & \\
\hline Adjusted $\mathrm{pH}$ & 10.2 & 10.5 & 10.8 & 10.2 & 10.5 & 10.8 & 8.0 \\
\hline \multicolumn{8}{|l|}{ Analysis (ppm) } \\
\hline $\mathrm{Ca}$ & 10 & 16 & 6 & 4 & 6 & 6 & 120 \\
\hline $\mathrm{SiO}_{2}$ & 68 & 73 & 80 & 80 & 91 & 100 & 155 \\
\hline${\mathrm{MgO} / \mathrm{SiO}_{2}}_{2}$ & 2.3 & 2.4 & 2.7 & 2.7 & 3.1 & 3.6 & \\
\hline $\begin{array}{c}\text { Chemical } \\
\text { Additions (ppm) }\end{array}$ & \multicolumn{3}{|c|}{ Temperature $60^{\circ} \mathrm{C}$} & \multicolumn{3}{|c|}{ Temperature $50^{\circ} \mathrm{C}$} & \\
\hline $\mathrm{CaO}$ & 189 & 265 & 605 & 121 & 181 & 363 & \\
\hline MgO & 200 & 200 & 200 & 200 & 200 & 200 & \\
\hline $\mathrm{Na}_{2} \mathrm{CO}_{3}$ & 300 & 397 & 900 & 180 & 271 & 545 & \\
\hline Adjusted $\mathrm{pH}$ & 10.2 & 10.5 & 10.8 & 10.2 & 10.5 & 10.8 & 8.0 \\
\hline Analysis (ppm) & & & & & & & \\
\hline $\mathrm{Ca}$ & 16 & 12 & 4 & 12 & 20 & 8 & 120 \\
\hline $\mathrm{SiO}_{2}$ & 123 & 103 & 113 & 138 & 138 & 130 & 155 \\
\hline $\mathrm{MgO} / \mathrm{SiO}_{2}$ & 6.3 & 3.9 & 4.8 & 11.8 & 11.8 & 8.0 & \\
\hline
\end{tabular}




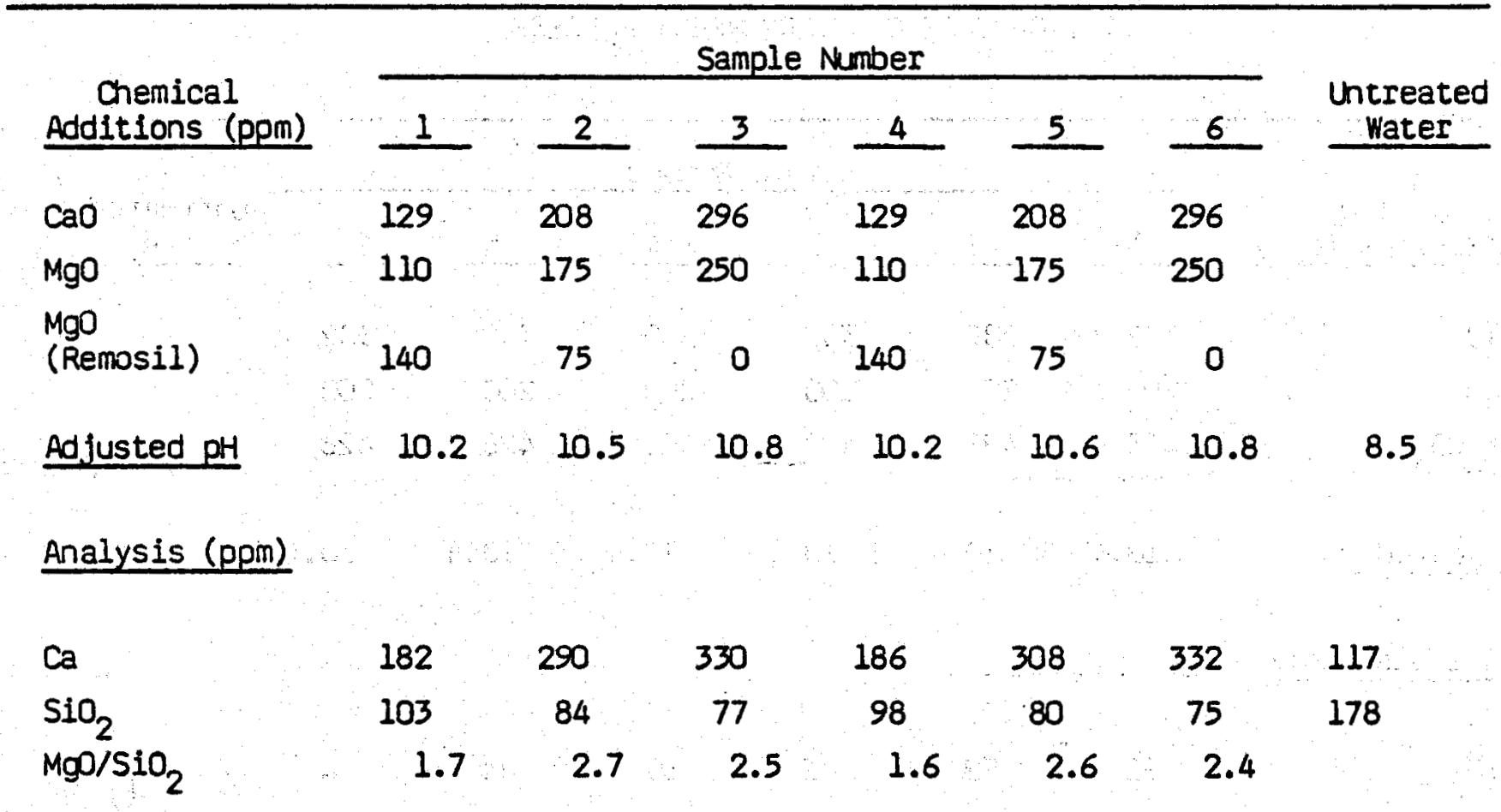

TABLE A-6. WATER TREATED WITH REMOSIL AT 60\% (PH ADJUSTED WITH NaOH)

\begin{tabular}{|c|c|c|c|c|c|c|c|}
\hline \multirow{2}{*}{$\begin{array}{l}\text { Chemical } \\
\text { Additions (ppm) }\end{array}$} & \multicolumn{6}{|c|}{ Sample Number } & \multirow{2}{*}{$\begin{array}{c}\text { Untreated } \\
\text { Water }\end{array}$} \\
\hline & 1 & 2 & 3 & 4 & 5 & 6 & \\
\hline $\mathrm{MgO}$ & 125 & 250 & 375 & 500 & 625 & 750 & \\
\hline $\begin{array}{l}\mathrm{NaOH} \text { as } \\
\mathrm{CaCO}_{3}\end{array}$ & 0.014 & 0.010 & 0.003 & 0.002 & 0 & 0 & \\
\hline Adjusted pH & 10.2 & 10.2 & 10.2 & 10.2 & 10.2 & 10.2 & 8.4 \\
\hline Analysis & & & & & & & \\
\hline $\mathrm{SiO}_{2}$ (ppm) & 142 & 165 & 76 & 76 & 74 & 80 & 206 \\
\hline $\mathrm{MgO} / \mathrm{SiO}_{2}$ (ppm) & 2.0 & 6.2 & 2.9 & 3.9 & 4.7 & 6.0 & \\
\hline $\begin{array}{l}\text { pH after } \\
\text { MgO } \\
\text { addition }\end{array}$ & 9.4 & 9.8 & 10 & 10.1 & 10.2 & 10.2 & \\
\hline
\end{tabular}


TABLE A-7. WATER TREATED WITH REMOSIL TO SIMULATE

A TWO-STAGE COUNTERCIRRENT PROCESS

\begin{tabular}{|c|c|c|c|c|c|c|c|}
\hline \multirow{2}{*}{$\begin{array}{l}\text { Chemical } \\
\text { Additions (ppm) }\end{array}$} & \multicolumn{6}{|c|}{ Sample Number } & \multirow{2}{*}{$\begin{array}{c}\text { Untreated } \\
\text { Water } \\
\end{array}$} \\
\hline & 1 & 2 & 3 & 4 & 5 & 6 & \\
\hline $\mathrm{CaO}$ & 302 & 302 & 302 & 302 & 302 & 302 & \\
\hline MgO & 200 & 200 & 200 & 200 & 200 & 200 & \\
\hline $\mathrm{Na}_{2} \mathrm{CO}_{3}$ & 428 & 428 & 428 & 428 & 428 & 428 & \\
\hline Adjusted pH & 10.4 & 10.4 & 10.4 & 10.4 & 10.4 & 10.4 & 8.4 \\
\hline Analysis (ppm) & & & & & & & \\
\hline $\mathrm{SiO}_{2}$ & 92 & 92 & 86 & 97 & 84 & 94 & 165 \\
\hline $\mathrm{MgO} / \mathrm{SiO}_{2}$ & 2.7 & 2.7 & 2.5 & 2.9 & 2.5 & 2.8 & \\
\hline
\end{tabular}

(Samples were filtered and returned to constant temperature bath.)

Chemical

Additions (ppm)

$\mathrm{MgO}$

25

Analysis (ppm)

$\mathrm{SiO}_{2}$

$\mathrm{MgO} / \mathrm{SiO}_{2}$

(Step 2)

${\mathrm{MgO} / \mathrm{SiO}_{2}}_{2}$

(Process)
$50 \quad 40$

0.6

1.0

2.0

2.0

2.0

2.3

2.5

25

22

1.3

1.6

2.5

2.9

2.8 
TABLE A-8. WATER TREATED WITH CARBONATED SOLUTIONS OF MAGNESIUM OXIDE AT 600 C

\begin{tabular}{|c|c|c|c|c|c|c|c|}
\hline \multirow[b]{2}{*}{$\begin{array}{c}\text { Chemical } \\
\text { Additions (ppm) }\end{array}$} & \multicolumn{6}{|c|}{ Sample Number } & \multirow[b]{2}{*}{$\begin{array}{c}\text { Untreated } \\
\text { Water } \\
\end{array}$} \\
\hline & $1^{a}$ & $2^{a}$ & $3^{a}$ & $4^{b}$ & $5^{b}$ & $6^{b}$ & \\
\hline $\mathrm{CaO}$ & 386 & 483 & 569 & 334 & 427 & 540 & \\
\hline $\mathrm{MgO}$ & 200 & 200 & 200 & 200 & 200 & 200 & \\
\hline Ad justed $\mathrm{pH}$ & 10.2 & 10.5 & 10.8 & 10.2 & 10.5 & 10.8 & 8.3 \\
\hline \multicolumn{8}{|l|}{ Analysis (ppm) } \\
\hline $\mathrm{SiO}_{2}$ & 32 & 33 & 38 & 32 & 34 & 36 & 180 \\
\hline $\mathrm{MgO} / \mathrm{SiO}_{2}$ & 1.4 & 1.4 & 1.4 & 1.4 & 1.4 & 1.4 & \\
\hline $\begin{array}{c}\text { Chemical } \\
\text { Additions (ppm) }\end{array}$ & $7^{c}$ & $8^{c}$ & $9^{c}$ & $10^{d}$ & $11^{d}$ & $12^{d}$ & $\begin{array}{c}\text { Untreated } \\
\text { Water } \\
\end{array}$ \\
\hline $\mathrm{CaO}$ & 357 & 439 & 556 & 340 & 436 & 550 & \\
\hline MgO & 200 & 200 & 200 & 200 & 200 & 200 & \\
\hline Ad justed $\mathrm{pH}$ & 10.2 & 10.5 & 10.8 & 10.2 & 10.5 & 10.8 & 8.3 \\
\hline Analysis (ppm) & & & & & & & \\
\hline $\begin{array}{l}\mathrm{SiO}_{2} \\
\mathrm{MgO} / \mathrm{SiO}_{2}\end{array}$ & $\begin{array}{l}32 \\
1.4\end{array}$ & $\begin{array}{l}39 \\
1.4\end{array}$ & 1.4 & $\begin{array}{l}35 \\
1.4\end{array}$ & $\begin{array}{l}36 \\
1.4\end{array}$ & $\begin{array}{l}30 \\
1.3\end{array}$ & 180 \\
\hline a. As light gra & & & & & & & \\
\hline b. As heavy gra & & & & & & & \\
\hline c. As dolomitic & Lme. & & & & & & \\
\hline d. As Remosil. & & & & & & & \\
\hline
\end{tabular}


TABLE A-9. WATER TREATED WITH MAGNESIUM SULFATE (ESOM SALT) AT 600

\begin{tabular}{|c|c|c|c|c|c|c|c|}
\hline \multirow{2}{*}{$\begin{array}{c}\text { Chemical } \\
\text { Additions (ppm) }\end{array}$} & \multicolumn{6}{|c|}{ Sample Number } & \multirow{2}{*}{$\begin{array}{l}\text { Untreated } \\
\text { Water }\end{array}$} \\
\hline & 1 & 2 & 3 & 4 & 5 & 6 & \\
\hline $\mathrm{CaO}$ & 740 & 740 & 740 & 740 & 815 & 890 & \\
\hline MgO & 50 & 100 & 150 & 200 & 225 & 250 & \\
\hline Adjusted pH & 10.2 & 10.2 & 10.2 & 10.2 & 10.2 & 10.2 & 8.3 \\
\hline Analysis (ppm) & & & & & & & \\
\hline $\mathrm{Ca}$ & 206 & 300 & 480 & 520 & 560 & 600 & 140 \\
\hline $\mathrm{SiO}_{2}$ & 85 & 50 & 25 & 12 & 5 & 3.6 & 163 \\
\hline $\mathrm{MgO} / \mathrm{SIO}_{2}$ & 0.6 & 0.9 & 1.1 & 1.3 & 1.4 & 1.6 & \\
\hline
\end{tabular}

TABLE A-10. WATER TREATED WITH MAGNESIUM SULFATE AND SOOA ASH AT $60^{\circ} \mathrm{C}$

\begin{tabular}{|c|c|c|c|c|c|c|c|}
\hline \multirow{2}{*}{$\begin{array}{c}\text { Chemical } \\
\text { Additions (ppm) }\end{array}$} & \multicolumn{6}{|c|}{ Sample Number } & \multirow{2}{*}{$\begin{array}{l}\text { Untreated } \\
\text { Water }\end{array}$} \\
\hline & 1 & 2 & 3 & 4 & 5 & 6 & \\
\hline $\mathrm{CaO}$ & 350 & 350 & 500 & 620 & 780 & 900 & \\
\hline MgO & 50 & 100 & 150 & 200 & 225 & 250 & \\
\hline $\mathrm{Na}_{2} \mathrm{CO}_{3}$ & 375 & 375 & 600 & 750 & 1020 & 1200 & \\
\hline Adjusted pH & 10.2 & 10.2 & 10.2 & 10.2 & 10.2 & 10.2 & 8.3 \\
\hline \multicolumn{8}{|l|}{ Analysis (ppm) } \\
\hline $\mathrm{Ca}$ & $N D^{a}$ & 32 & 2 & 16 & 24 & 20 & 140 \\
\hline $\mathrm{SiO}_{2}$ & 95 & 74 & 43 & 23 & 9 & 7 & 163 \\
\hline $\mathrm{MgO} / \mathrm{SiO}_{2}$ & 0.7 & 1.1 & 1.3 & 1.4 & 1.5 & 1.8 & \\
\hline
\end{tabular}

a. ND denotes none detected. 
TABLE A-11. WATER TREATED WITH EQUTMOAAR QUANTITIES OF MAGNESTUM SULFATE AND SODIUM BICARBONATE AT $60^{\circ} \mathrm{C}$

\begin{tabular}{|c|c|c|c|c|c|c|c|}
\hline \multirow{2}{*}{$\begin{array}{c}\text { Ohemical } \\
\text { Additions (ppm) }\end{array}$} & \multicolumn{6}{|c|}{ Sample Nunber } & \multirow{2}{*}{$\begin{array}{l}\text { Untreated } \\
\text { Water }\end{array}$} \\
\hline & 1 & 2 & 3 & 4 & 5 & 6 & \\
\hline $\mathrm{CaO}$ & 1037 & 1133 & 1200 & 1333 & 1451 & 1667 & \\
\hline Mgo & 50 & 100 & 150 & 200 & 225 & 250 & \\
\hline Adjusted pH & 10.2 & 10.2 & 10.2 & 10.2 & 10.2 & 10.2 & 8.3 \\
\hline Analys is (ppm) & & & & & & & \\
\hline $\mathrm{Ca}$ & 40 & 40 & 10 & 40 & 20 & 16 & 140 \\
\hline $\mathrm{SiO}_{2}$ & 124 & 102 & 71 & 50 & 35 & 31 & 163 \\
\hline $\mathrm{MgO} / \mathrm{SHO}_{2}$ & 1.3 & 1.6 & 1.6 & 1.8 & 1.6 & 1.7 & \\
\hline
\end{tabular}

TABLE A-12. WATER TREATED WITH MAGNESIUM SULFATE AT 600

\begin{tabular}{|c|c|c|c|c|c|c|c|}
\hline \multirow{2}{*}{$\begin{array}{c}\text { Chemical } \\
\text { Additions (ppm) }\end{array}$} & \multicolumn{6}{|c|}{ Sample Nunber } & \multirow{2}{*}{$\begin{array}{l}\text { Untreated } \\
\text { Water }\end{array}$} \\
\hline & 1 & 2 & 3 & 4 & 5 & 6 & \\
\hline $\mathrm{CaO}$ & 378 & 503 & 631 & 923 & 1134 & 1304 & \\
\hline MgO & 50 & 100 & 150 & 200 & 300 & 400 & \\
\hline $\mathrm{Na}_{2} \mathrm{CO}_{3}$ & 658 & 874 & 1100 & 1710 & 1975 & 2270 & \\
\hline Adjusted pH & 10.4 & 10.4 & 10.4 & 10.4 & 10.4 & 10.4 & 8.4 \\
\hline \multicolumn{8}{|l|}{ Analysis (ppm) } \\
\hline $\begin{array}{l}\mathrm{SiO}_{2} \\
\mathrm{MgO} / \mathrm{SHO}_{2}\end{array}$ & $\begin{array}{c}63 \\
0.5\end{array}$ & $\begin{array}{l}42 \\
0.8\end{array}$ & $\begin{array}{l}22 \\
1.0\end{array}$ & $\begin{array}{l}13 \\
1.3\end{array}$ & $\begin{array}{l}6 \\
1.8\end{array}$ & $\begin{array}{l}5 \\
3.0\end{array}$ & 173 \\
\hline
\end{tabular}

a. System made by acidification of MgO suspension with $\mathrm{H}_{2} \mathrm{SO}_{4}$. 
TABLE A-13. WATER TREATED WITH MAGNESIUM SULFATE AND SODA ASHa AT $60^{\circ} \mathrm{C}$

\begin{tabular}{|c|c|c|c|c|c|c|c|}
\hline \multirow{2}{*}{$\begin{array}{c}\text { Chemical } \\
\text { Additions (ppm) }\end{array}$} & \multicolumn{6}{|c|}{ Sample Number } & \multirow{2}{*}{$\begin{array}{c}\text { Untreated } \\
\text { Water }\end{array}$} \\
\hline & 1 & 2 & 3 & 4 & 5 & 6 & \\
\hline $\mathrm{CaO}$ & 121 & 129 & 129 & 118 & 57 & 57 & \\
\hline $\mathrm{MgO}$ & 50 & 100 & 150 & 200 & 300 & 400 & \\
\hline Adjusted $\mathrm{pH}$ & 10.4 & 10.4 & 10.4 & 10.4 & 10.4 & 10.4 & 8.6 \\
\hline Analysis (ppm) & & & & & & & \\
\hline $\mathrm{SiO}_{2}$ & 29 & 14 & 5 & -4 & 3 & 3 & 176 \\
\hline $\mathrm{MgO} / \mathrm{SiO}_{2}$ & 0.3 & 0.6 & 0.9 & 1.2 & 1.7 & 2.3 & \\
\hline
\end{tabular}

a. System produced by addition of equimolar quantities of $\mathrm{MgO}$ and $\mathrm{Na}_{2} \mathrm{CO}_{3}$, then $\mathrm{H}_{2} \mathrm{O}$ and $\mathrm{H}_{2} \mathrm{SO}_{4}$ until solution clears.

TABLE A-14. WATER TREATED WITH MAGNESIUM CHLORIDEa AT $600^{\circ} \mathrm{C}$ AND $\mathrm{PH} 10.2$.

\begin{tabular}{|c|c|c|c|c|c|c|c|}
\hline \multirow{2}{*}{$\begin{array}{l}\text { Chemical } \\
\text { Additions (ppm) }\end{array}$} & \multicolumn{6}{|c|}{ Sample Number } & \multirow{2}{*}{$\begin{array}{l}\text { Untreated } \\
\text { Water } \\
\end{array}$} \\
\hline & 1 & 2 & 3 & 4. & 5 & 6 & \\
\hline $\mathrm{CaO}$ & 260 & 296 & 335 & 407 & 453 & 475 & \\
\hline MgO & 25 & 50 & 75 & 100 & 125 & 150 & \\
\hline $\mathrm{Na}_{2} \mathrm{CO}_{3}$ & 332 & 372 & 426 & 518 & 577 & 605 & \\
\hline Adjusted $\mathrm{pH}$ & 10.2 & 10.2 & 10.2 & 10.2 & 10.2 & 10.2 & 8.3 \\
\hline \multicolumn{8}{|l|}{ Analys is (ppm) } \\
\hline $\mathrm{Ca}$ & 16 & 14 & 12 & 10 & 12 & 8 & 140 \\
\hline $\mathrm{SiO}_{2}$ & 106 & 94 & 62 & 55 & 39 & 30 & 163 \\
\hline $\mathrm{MgO} / \mathrm{SiO}_{2}$ & 0.4 & 0.7 & 0.7 & 0.9 & 1.0 & 1.1 & \\
\hline
\end{tabular}

a. System produced by addition of $\mathrm{HCl}$ to $\mathrm{MgO}$ suspension until solution clears. 


\begin{tabular}{|c|c|c|c|c|c|c|c|}
\hline \multirow{2}{*}{$\begin{array}{c}\text { Chemical } \\
\text { Additions (ppm) }\end{array}$} & \multicolumn{6}{|c|}{ Sample - Number } & \multirow[b]{2}{*}{$\begin{array}{c}\text { Untreated } \\
\text { Water }\end{array}$} \\
\hline & 1 & 2 & 3 & 4 & 5 & 6 & \\
\hline $\mathrm{CaO}$ & 1000 & 1000 & 1000 & 1000 & 1000 & 1000 & \\
\hline $\mathrm{MgO}$ & 40 & 80 & 100 & 125 & 140 & 155 & \\
\hline Adjusted $\mathrm{pH}$ & 11.2 & 11.2 & 11.2 & 11.2 & 11.2 & 11.2 & 8.3 \\
\hline Analysis (ppm) & & & & & & & ' \\
\hline $\mathrm{SiO}_{2}$ & 23 & 15 & 14 & 12 & 11 & 9 & 163 \\
\hline $\mathrm{MgO} / \mathrm{SiO}_{2}$ & 0.3 & 0.5 & 0.7 & 0.8 & 0.9 & 1.0 & \\
\hline
\end{tabular}

a. System produced by addition of concentrated $\mathrm{HCl}$ to MgO suspension until solution clears. 
TABLE A-16. WATER TREATED WITH MAGNESIUM OXIDE

FOLLOWING PH ADJUSTMENT AT $60^{\circ} \mathrm{C}$

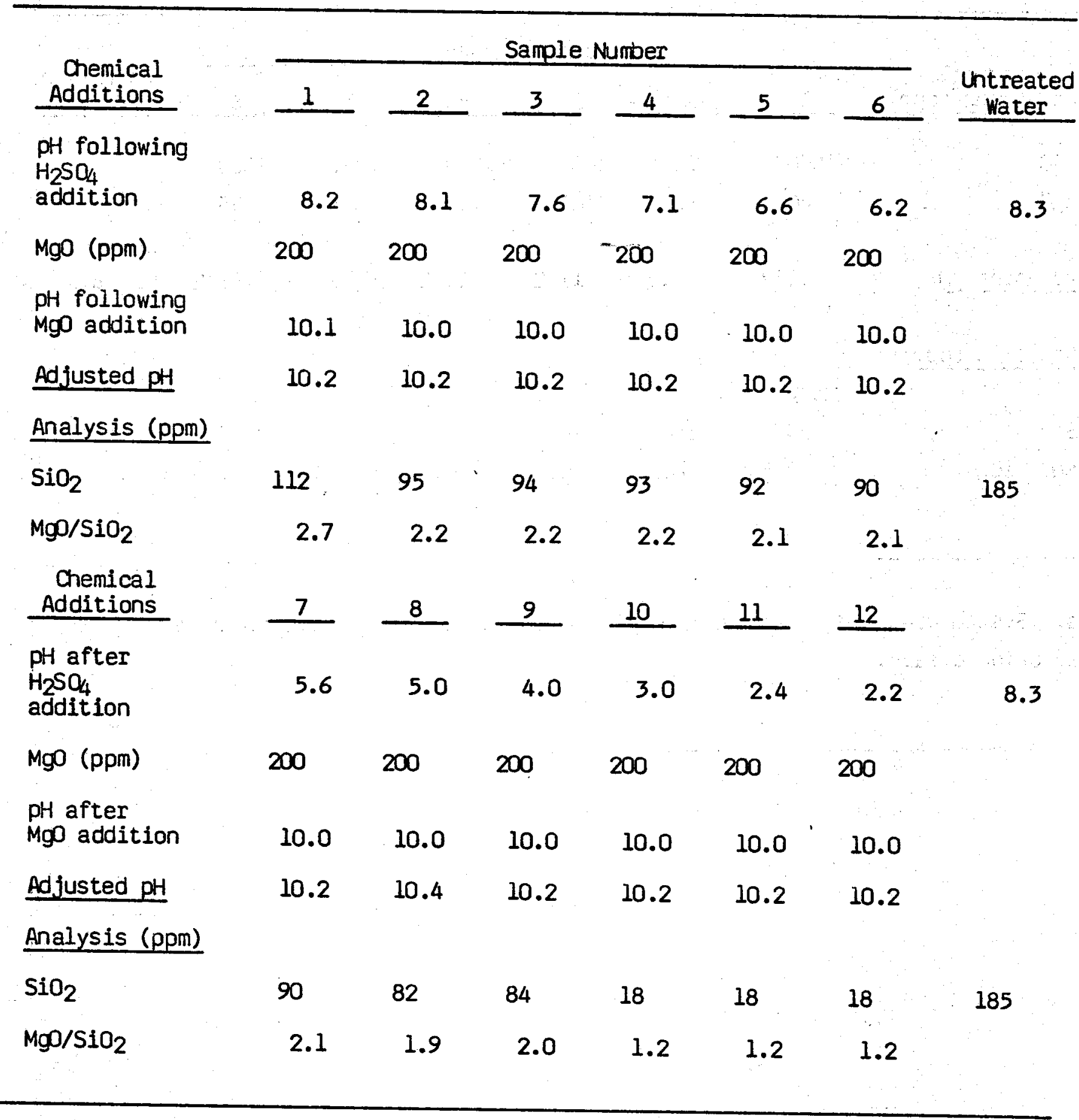


TABLE A-17. WATER TREATED WITH FERROUS SULFATE

AT $60^{\circ} \mathrm{C}$ AND VARYING PH (PH ADJUSTED WITH NaOH)

\begin{tabular}{|c|c|c|c|c|c|c|c|}
\hline \multirow[b]{2}{*}{$\begin{array}{c}\text { Chemical } \\
\text { Additions (ppm) }\end{array}$} & \multicolumn{6}{|c|}{ Sample Number } & \multirow[b]{2}{*}{$\begin{array}{l}\text { Untreatec } \\
\text { Water }\end{array}$} \\
\hline & 1 & 2 & 3 & 4 & 5 & 6 & \\
\hline $\mathrm{Fe}$ & 250 & 250 & 250 & 250 & 250 & 250 & \\
\hline $\begin{array}{l}\mathrm{NaOH} \text { as } \\
\mathrm{CaCO}_{3}\end{array}$ & 0.066 & 0.071 & 0.078 & 0.083 & 0.102 & 0.138 & \\
\hline Adjusted pH & 8.0 & 8.6 & 9.0 & 9.6 & 10.0 & 10.4 & 8.3 \\
\hline Analys is (ppm) & & & & & & & \\
\hline $\mathrm{SiO}_{2}$ & 65 & 27 & 23 & 20 & 21 & 22 & 185 \\
\hline $\mathrm{Fe} / \mathrm{SiO}_{2}$ & 2.1 & 1.6 & 1.5 & 1.5 & 1.5 & 1.5 & \\
\hline
\end{tabular}

TABLE A-18. WATER TREATED WITH FERRIC CHLORIDE AT 600 C

\begin{tabular}{|c|c|c|c|c|c|c|c|}
\hline \multirow{2}{*}{$\begin{array}{c}\text { Chemical } \\
\text { Additions (ppm) }\end{array}$} & \multicolumn{6}{|c|}{ Sample Number } & \multirow{2}{*}{$\begin{array}{l}\text { Untreated } \\
\text { Water }\end{array}$} \\
\hline & 1 & 2 & 3 & 4 & 5 & 6 & \\
\hline $\mathrm{Fe}$ & 36 & 72 & 108 & 144 & 180 & 226 & \\
\hline $\mathrm{CaO}$ & 166 & 333 & 394 & 787 & 1157 & 1483 & \\
\hline Adjusted pH & 8.2 & 7 & 7.1 & 6.5 & 8.8 & 8.8 & 8.3 \\
\hline Analysis (ppm) & & & & & & & \\
\hline $\mathrm{SiO}_{2}$ & 125 & 113 & 93 & 47 & 17.0 & 12 & 185 \\
\hline $\mathrm{Fe} / \mathrm{SiO}_{2}$ & 0.6 & 1.0 & 1.2 & 1.0 & 1.1 & 1.3 & \\
\hline
\end{tabular}


TABLE A-19. TABULATION OF MAGNESIUM SYSTEMS AT $60^{\circ} \mathrm{C}$

\begin{tabular}{|c|c|c|c|c|c|c|}
\hline \multirow[b]{2}{*}{$\begin{array}{l}\text { Original } \\
\mathrm{SiO}_{2}(\mathrm{ppm})\end{array}$} & \multicolumn{2}{|c|}{ Additions } & \multirow[b]{2}{*}{$\begin{array}{c}\text { Final } \\
\mathrm{SiO}_{2}(\mathrm{ppm}) \\
\end{array}$} & \multirow[b]{2}{*}{$\mathrm{pH}$} & \multirow[b]{2}{*}{$\begin{array}{l}\text { MgO } \\
\text { Source (ppm) }\end{array}$} & \multirow[b]{2}{*}{$\begin{array}{c}\mathrm{MgO} / \mathrm{SiO}_{2} \\
\text { Removed (ppm) }\end{array}$} \\
\hline & $\begin{array}{l}\mathrm{MgO} \\
(\mathrm{ppm})\end{array}$ & $\begin{array}{c}\mathrm{Ca0} \\
\text { (ppm) }\end{array}$ & & & & \\
\hline 164 & 74 & 88 & 160 & 9.2 & $\mathrm{DL}$ & 18.5 \\
\hline 164 & 148 & 176 & 138 & 10.0 & $D L$ & 5.7 \\
\hline 164 & 222 & 264 & 110 & 10.6 & $D L$ & 4.1 \\
\hline 164 & 296 & 352 & 140 & 11.0 & DL & 12.3 \\
\hline 164 & 370 & 440 & 114 & 11.2 & $D L$ & 6.9 \\
\hline 164 & 444 & 528 & 108 & 11.3 & $D L$ & 7.9 \\
\hline 176 & 200 & 200 & 68 & 10.2 & $M(R)$ & 1.9 \\
\hline 176 & 200 & 370 & 65 & 10.5 & $M(R)$ & 1.8 \\
\hline 176 & 200 & 400 & 66 & 10.8 & $M(R)$ & 1.8 \\
\hline 176 & 200 & 284 & 78 & 10.2 & $M(H)$ & 2.0 \\
\hline 176 & 200 & 321 & 74 & 10.5 & $M(H)$ & 2.0 \\
\hline 176 & 200 & 435 & 68 & 10.8 & $M(H)$ & 1.9 \\
\hline 176 & 200 & 152 & 76 & 10.2 & $M(L)$ & 2.0 \\
\hline 176 & 200 & 208 & 81 & 10.5 & $M(L)$ & 2.1 \\
\hline 176 & 200 & 380 & 73 & 10.8 & $M(L)$ & 1.9 \\
\hline 176 & 200 & 387 & 92 & 10.2 & $D L$ & 2.7 \\
\hline 176 & 200 & 537 & 88 & 10.5 & $\mathrm{DL}$ & 2.9 \\
\hline 176 & 200 & 637 & 90 & 10.8 & $D L$ & 2.7 \\
\hline 178 & 250 & 129. & 103 & 10.2 & $a+M(R)$ & 1.7 \\
\hline 178 & 250 & 208 & 84 & 10.5 & $D L+M(R)$ & 2.7 \\
\hline
\end{tabular}


TABLE A-19. (Continued)

\begin{tabular}{|c|c|c|c|c|c|c|}
\hline $\begin{array}{l}\text { Original } \\
\mathrm{SiO}_{2}(\mathrm{ppm})\end{array}$ & $\frac{\text { Addit }}{\text { Mgo }}$ & $\frac{\text { ons }}{\text { Ca0 }}$ & $\begin{array}{c}\text { Final } \\
\mathrm{SiO}_{2}(\mathrm{ppm}) \\
\end{array}$ & $\mathrm{pH}$ & $\begin{array}{c}\text { MgO } \\
\text { Source (ppm) }\end{array}$ & $\begin{array}{c}\mathrm{MgO} / \mathrm{SiO}_{2} \\
\text { Removed (ppm) }\end{array}$ \\
\hline 178 & 250 & 296 & 77 & 10.8 & $\mathrm{DL}$ & 2.5 \\
\hline 178 & 250 & 129 & 98 & 10.2 & $D L+M(R)$ & 1.6 \\
\hline 178 & 250 & 208 & 80 & 10.6 & $\alpha+M(R)$ & 2.6 \\
\hline 178 & 250 & 296 & 75 & 10.8 & DL & 2.4 \\
\hline 206 & 125 & 0 & 142 & 10.2 & $M(R)$ & 2.0 \\
\hline 206 & 250 & 0. & 165 & 10.2 & $M(R)$ & 6.2 \\
\hline 206 & 375 & 0 & 76 & 10.2 & $M(R)$ & 2.9 \\
\hline 206 & 500 & 0 & 76 & 10.2 & $M(R)$ & 3.9 \\
\hline 206 & 625 & 0 & 74 & 10.2 & $M(R)$ & 4.7 \\
\hline 206 & 750 & 0 & 80 & 10.2 & $M(R)$ & 6.0 \\
\hline 180 & 200 & 386 & 32 & 10.2 & $M(L)+C_{2}$ & 1.4 \\
\hline 180 & 200 & 483 & 33 & 10.5 & $M(L)+C_{2}$ & 1.4 \\
\hline 180 & 200 & 569 & 38 & 10.8 & $M(L)+\infty_{2}$ & 1.4 \\
\hline 180 & 200 & 334 & 32 & 10.2 & $M(H)+\infty_{2}$ & 1.4 \\
\hline 180 & 200 & 427 & 34 & 10.5 & $M(H)+C_{2}$ & 1.4 \\
\hline 180 & 200 & 540 & 36 & 10.8 & $M(H)+\infty_{2}$ & 1.4 \\
\hline 180 & 200 & 357 & 32 & 10.2 & $\mathrm{DL}+\mathrm{CO}_{2}$ & 1.4 \\
\hline 180 & 200 & 439 & 39 & 10.5 & $\mathrm{DL}+\mathrm{CO}_{2}$ & 1.4 \\
\hline 180 & 200 & 556 & 41 & 10.8 & $\mathrm{DL}+\mathrm{CO}_{2}$ & 1.4 \\
\hline 180 & 200 & 340 & 35 & 10.2 & $M(R)+\infty_{2}$ & 1.4 \\
\hline 180 & 200 & 436 & 36 & 10.5 & $M(R)+\infty_{2}$ & 1.4 \\
\hline
\end{tabular}


TABLE A-19. (Continued)

\begin{tabular}{|c|c|c|c|c|c|c|}
\hline \multirow{2}{*}{$\begin{array}{l}\text { Original } \\
\mathrm{SiO}_{2}(\mathrm{ppm}) \\
\end{array}$} & \multicolumn{2}{|c|}{ Additions } & \multirow[b]{2}{*}{$\begin{array}{c}\text { Final } \\
\mathrm{SiO}_{2}(\mathrm{ppm}) \\
\end{array}$} & \multirow[b]{2}{*}{$\mathrm{pH}$} & \multirow[b]{2}{*}{$\begin{array}{c}\text { Mgo } \\
\text { Source (ppm) } \\
\end{array}$} & \multirow[b]{2}{*}{$\begin{array}{l}\mathrm{MgO} / \mathrm{SiO}_{2} \\
\text { Removed (ppm) }\end{array}$} \\
\hline & $\begin{array}{l}\text { MgO } \\
\text { (ppm) }\end{array}$ & $\begin{array}{c}\mathrm{CaO} \\
(\mathrm{ppm})\end{array}$ & & & & \\
\hline 180 & 200 & 550 & 30 & 10.8 & $M(R)+\infty_{2}$ & 1.3 \\
\hline 163 & 50 & 740 & 85 & 10.2 & EPS & 0.6 \\
\hline 163 & 100 & 740 & 50 & 10.2 & EPS & 0.9 \\
\hline 163 & 150 & 740 & 25 & 10.2 & EPS & 1.1 \\
\hline 163 & 200 & 740 & 12 & 10.2 & EPS & 1.3 \\
\hline 163 & 225 & 815 & 5 & 10.2 & EPS & 1.4 \\
\hline 163 & 250 & 890 & 4 & 10.2 & EPS & 1.6 \\
\hline 163 & 50 & 350 & 95 & 10.2 & $E P S+S A$ & 0.7 \\
\hline 163 & 100 & 350 & 74 & 10.2 & $E P S+S A$ & 1.1 \\
\hline 163 & 150 & 500 & 43 & 10.2 & $E P S+S A$ & 1.3 \\
\hline 163 & 200 & 620 & 23 & 10.2 & EPS+SA & 1.4 \\
\hline 163 & 225 & 780 & 9 & 10.2 & $E P S+S A$ & 1.5 \\
\hline 163 & 250 & 900 & 7 & 10.2 & $E P S+S A$ & 1.8 \\
\hline 163 & 50 & 1037 & 124 & 10.2 & EPS+NAB & 1.3 \\
\hline 163 & 100 & 1133 & 102 & 10.2 & EPS+NAB & 1.6 \\
\hline 163 & 150 & 1200 & 71 & 10.2 & $E P S+N A B$ & 1.6 \\
\hline 163 & 200 & 1333 & 50 & 10.2 & $\mathrm{EPS}+\mathrm{NAB}$ & 1.8 \\
\hline 163 & 225 & 1451 & 35 & 10.2 & $\mathrm{EPS}+\mathrm{NAB}$ & 1.6 \\
\hline 163 & 250 & 1667 & 31 & 10.2 & $E P S+N A B$ & 1.7 \\
\hline 173 & 50 & 378 & 63 & 10.4 & $\mathrm{MgSO}_{4}(\mathrm{R})$ & 0.5 \\
\hline 173 & 100 & 503 & 42 & 10.4 & $\mathrm{MgSO}_{4}(\mathrm{R})$ & 0.8 \\
\hline
\end{tabular}


TABLE A-19. (Continued)

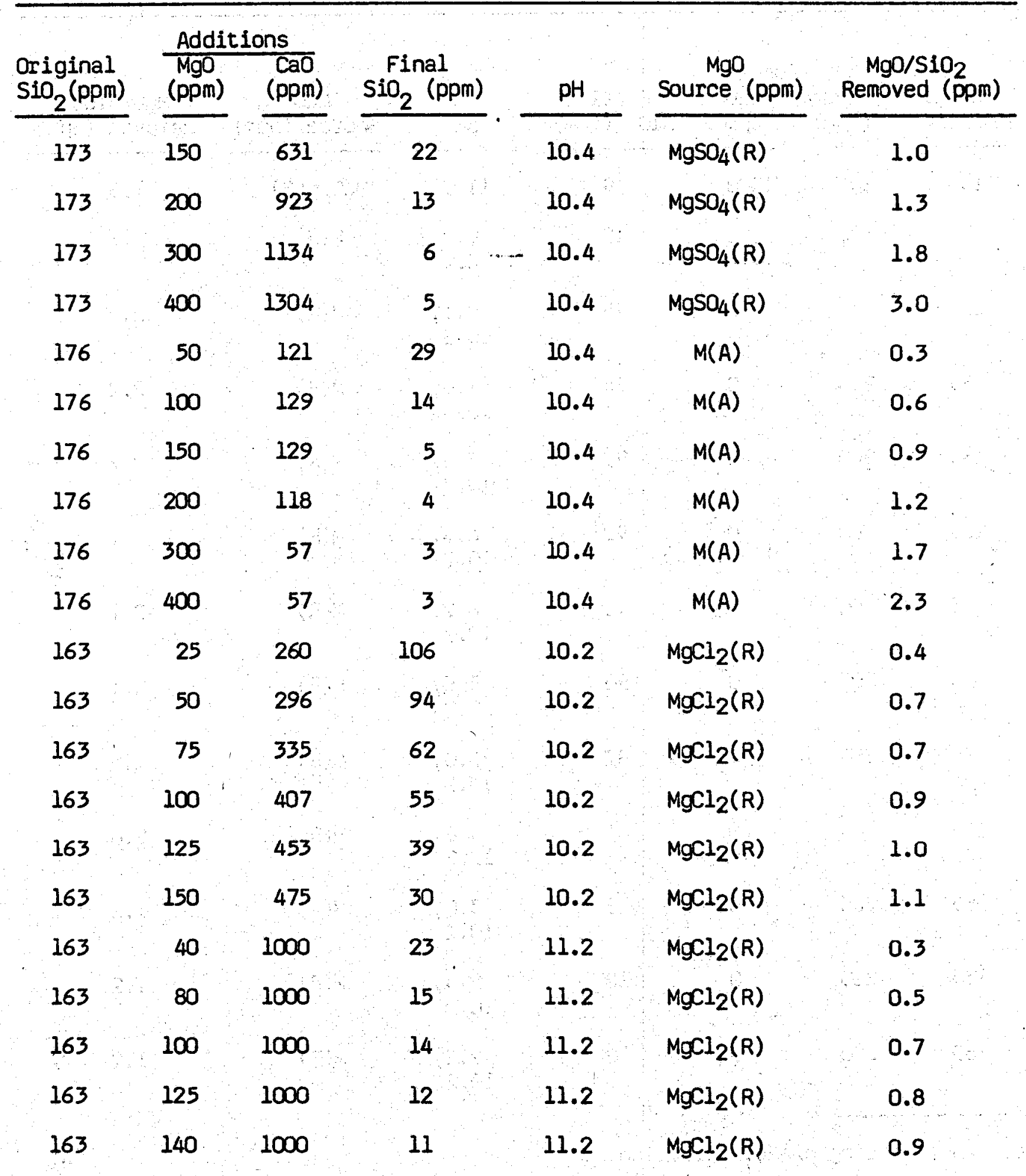


TABLE A-19. (Continued)

\begin{tabular}{|c|c|c|c|c|c|c|}
\hline & Addit & & & & & \\
\hline $\begin{array}{l}\text { Original } \\
\mathrm{SiO}_{2}(\mathrm{ppm}) \\
\end{array}$ & $\begin{array}{l}\mathrm{MgO} \\
(\mathrm{ppm})\end{array}$ & $\begin{array}{l}\mathrm{CaO} \\
(\mathrm{ppm})\end{array}$ & $\begin{array}{c}\text { Final } \\
\mathrm{SiO}_{2}(\mathrm{ppm}) \\
\end{array}$ & $\mathrm{pH}$ & $\begin{array}{c}\text { Mgo } \\
\text { Source (ppm) }\end{array}$ & $\begin{array}{l}\mathrm{MgO} / \mathrm{SiO}_{2} \\
\text { Removed (ppm) }\end{array}$ \\
\hline 163 & 155 & 1000 & 9 & 11.2 & $\mathrm{MgCl}_{2}(\mathrm{R})$ & 1.0 \\
\hline 185 & 200 & 0 & 112 & $\begin{array}{c}8.2^{\mathrm{a}} \\
10.2^{\mathrm{b}}\end{array}$ & $M(R)$ & 2.7 \\
\hline 185 & 200 & 0 & 95 & $\begin{array}{c}8.1 \\
10.2\end{array}$ & $M(R)$ & 2.2 \\
\hline 185 & 200 & 0 & 94 & $\begin{array}{l}7.6 \\
10.2\end{array}$ & $M(R)$ & 2.2 \\
\hline 185 & 200 & 0 & 93 & $\begin{array}{l}7.1 \\
10.2\end{array}$ & $M(R)$ & 2.2 \\
\hline 185 & 200 & 0 & 92 & $\begin{array}{r}6.6 \\
10.2\end{array}$ & $M(R)$ & 2.1 \\
\hline 185 & 200 & 0 & 90 & $\begin{array}{r}6.2 \\
10.2\end{array}$ & $M(R)$ & 2.1 \\
\hline 185 & 200 & 0 & 90 & $\begin{array}{c}5.6 \\
10.2\end{array}$ & $M(R)$ & 2.1 \\
\hline 185 & 200 & 0 & 82 & $\begin{array}{r}5.0 \\
10.2\end{array}$ & $M(R)$ & 1.9 \\
\hline 185 & 200 & 0 & 84 & $\begin{array}{c}4.0 \\
10.2\end{array}$ & $M(R)$ & 2.0 \\
\hline 185 & 200 & 0 & 18 & $\begin{array}{l}3.0 \\
10.2\end{array}$ & $M(R)$ & 1.2 \\
\hline 185 & 200 & 0 & 18 & $\begin{array}{c}2.4 \\
10.2\end{array}$ & $M(R)$ & 1.2 \\
\hline 185 & 200 & 0 & 18 & $\begin{array}{c}2.2 \\
10.2\end{array}$ & $M(R)$ & 1.2 \\
\hline
\end{tabular}

a. $\mathrm{pH}$ following preacidification.

b. Final $\mathrm{pH}$. 


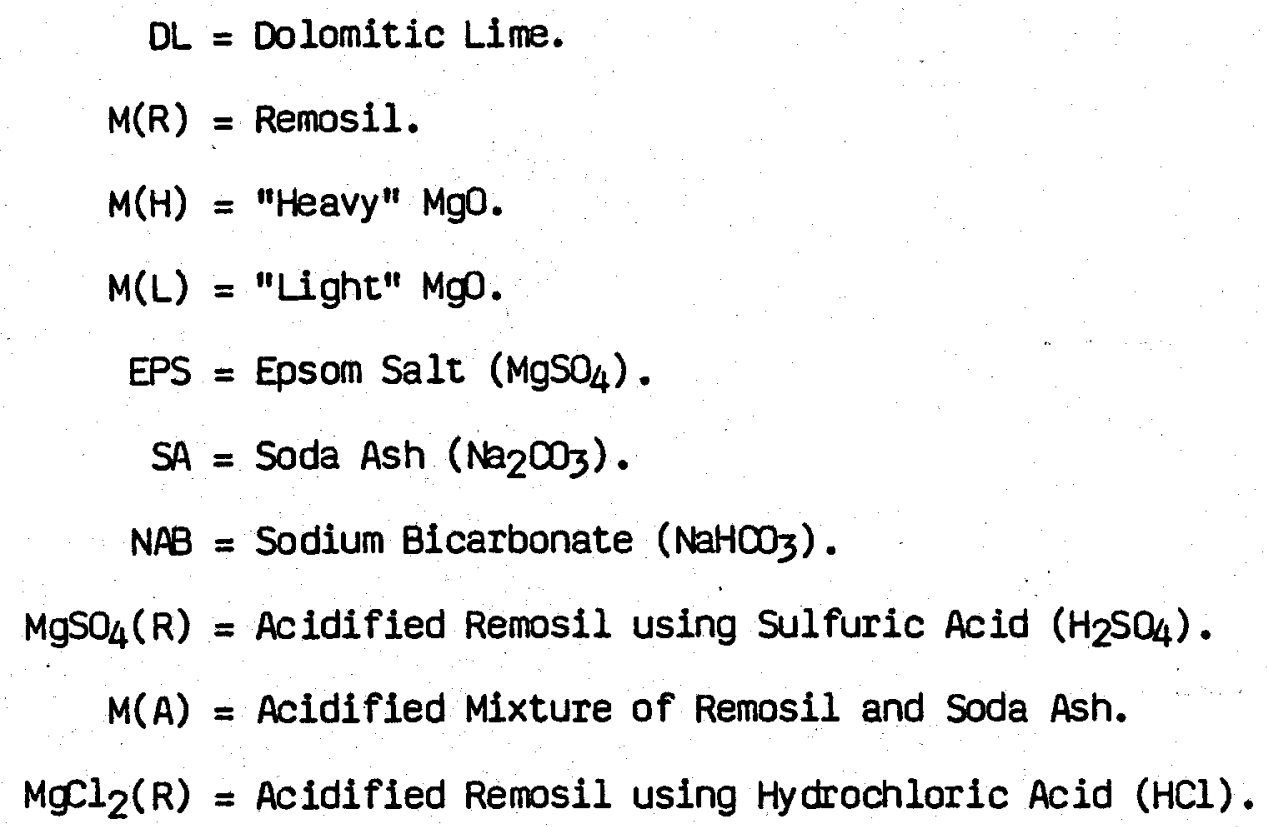

